\title{
Future Perspectives in the Pharmacological Treatment of Atrial Fibrillation and Ventricular Arrhythmias in Heart Failure
}

\author{
István Baczkó $^{*}$, István Leprán ${ }^{1}$, Loránd Kiss ${ }^{2}$, Danina M. Muntean ${ }^{3}$ and Peter E. Light ${ }^{4}$
}

\begin{abstract}
${ }^{I}$ Department of Pharmacology and Pharmacotherapy, University of Szeged; Hungary; ${ }^{2}$ Institute of Pharmaceutical Chemistry, Faculty of Pharmacy, University of Szeged; Hungary; ${ }^{3}$ Department of Pathophysiology, University of Medicine and Pharmacy Timişoara, Romania; ${ }^{4}$ Department of Pharmacology, Cardiovascular Research Centre and the Alberta Diabetes Institute, Li Ka Shing Research Centre, University of Alberta, Edmonton Alberta, Canada
\end{abstract}

\begin{abstract}
Heart failure (HF) is a clinical syndrome characterized by significant impairment of cardiac ventricular function. Atrial fibrillation (AF) is the most commonly observed sustained arrhythmia in clinical practice. Both $\mathrm{HF}$ and $\mathrm{AF}$ are associated with increased morbidity and mortality and their prevalence increases with age. Approximately $50 \%$ of patients with moderate HF die due to ventricular fibrillation that leads to sudden cardiac death. Patients with AF exhibit increased mortality due to HF and stroke. HF and AF often co-exist, and the development of the other condition further deteriorates prognosis. Both chronic HF and AF lead to structural and electrophysiological changes in the heart called remodeling, modifying therapeutic targets including those for antiarrhythmic intervention. Current pharmacological treatment of arrhythmias has major limitations due to low efficacy and serious adverse effects. In this review, the main aspects of electrical remodeling in $\mathrm{HF}$ and $\mathrm{AF}$ are discussed along with possible novel targets identified for future pharmacological antiarrhythmic therapy.
\end{abstract}

Keywords: Heart failure, atrial fibrillation, cardiac arrhythmias, electrical remodeling, potassium channel expression, multi-channel blocking drugs.

\section{OVERVIEW AND CURRENT STATUS}

\section{Epidemiology of Heart Failure, Atrial Fibrillation and their} Combination

Heart failure (HF) is a clinical syndrome resulting from a wide range of cardiovascular disorders, featuring significant impairment of cardiac function that leads to reduced ventricular filling or ejection of blood. HF markedly reduces health-related quality of life [1], causes significant morbidity and high mortality and represents an enormous economic burden for the health care system [2]. The incidence of HF is increasing with age, with 20 per 1000 persons 65-69 years old and more than 80 per 1000 persons older than 85 [3] and its prevalence is increasing in a continuously aging population [2]. In spite of the significant advances in the treatment of HF, mortality rates remain poor at approximately $50 \%$ of patients dying within 5 years of diagnosis [4]. Serious ventricular arrhythmias are common in HF [5] and approximately $50 \%$ of HF patients die due to ventricular fibrillation leading to sudden cardiac death (SCD), the rate of which is several times higher in HF patients compared to the general population [6]. In addition to severe ventricular arrhythmias, atrial arrhythmias often develop in heart failure. Bradycardia can develop due to sinoatrial function impairment [7] that can exacerbate cardiac dysfunction [8], can lead to syncope and haemodynamic collapse and can be resolved by application of implantable devices [9].

Atrial fibrillation (AF) is the most common sustained arrhythmia and it is associated with significant morbidity and mortality, especially due to the increased risk of heart failure and stroke [1012]. The prevalence of AF increases with age, with $0.5 \%$ of patients affected in the 50 year old range, $\sim 10 \%$ over the age of 80 [13] and the prediction is that it would increase in the future [14]. Heart failure and atrial fibrillation are often diagnosed in the same patient, and those with HF are more likely to develop AF compared to the

*Address correspondence to this author at the Department of Pharmacology and Pharmacotherapy, Faculty of Medicine, University of Szeged, Dóm tér 12., 6720 Szeged, Hungary; Tel: +36.62.546-109; Fax: +36.62.545-680; E-mail: baczko.istvan@med.u-szeged.hu general population [15]. The presence of AF in HF patients with either preserved or reduced left ventricular function carries an increased risk for all-cause mortality [16]. As the New York Heart Association (NYHA) functional classification based severity of HF increases, the prevalence of AF also increases [for a review see [17]. In patients with $\mathrm{HF}$ or $\mathrm{AF}$, the development of the other condition leads to further deterioration of an already poor prognosis. The analysis of the temporal relationship of AF and HF in patients from the Framingham Heart Study revealed that in patients with $\mathrm{HF}$, later development of $\mathrm{AF}$ was associated with increased mortality both in men and women [15]. It is therefore no coincidence that $\mathrm{AF}$ and HF were called the "two new epidemics of cardiovascular disease" [18]. Why do AF and HF so often co-exist? Many cardiovascular diseases are common risk factors for both $\mathrm{HF}$ and $\mathrm{AF}$ development [19]. These conditions (e.g. hypertension, valvular heart disease, coronary artery disease etc.) may eventually lead to structural and electrophysiological remodeling [20] and chronic neurohormonal activation that promote the development of both $\mathrm{AF}$ and HF [21]. In addition, once AF is present, it can facilitate HF due to rapid activation of the ventricles leading to tachycardia induced cardiomyopathy and maladaptive remodeling of the myocardium [22]. Furthermore, AF by itself is associated with decreased cardiac output [23]. Heart failure, on the other hand, can promote AF by increasing atrial pressure and atrial dilatation [24], by inducing atrial fibrosis [25], by its chronic activation of the reninangiotensin-aldosterone system that leads to further structural and electrophysiological remodeling.

\section{Pharmacological Treatment of $\mathrm{AF}$ in $\mathrm{HF}$}

Current pharmacological treatment options for the management of AF are sub-optimal, since high rates of AF recurrence are observed following cardioversion using currently available drugs [2628 ] and they have even more limited efficacy in patients with persistent/permanent AF and remodeled atria. Furthermore, the majority of these drugs were developed for the treatment of ventricular arrhythmias, therefore their ventricular electrophysiological effects can lead to pro-arrhythmic ventricular side effects. Therefore there is an unmet need for more efficacious and safer pharmacological 
management of AF [29]. The use of antiarrhythmic agents for the management of AF in patients with HF is even more limited, since the mortality increasing pro-arrhythmic side effects of these drugs in HF are of particular concern. Similar to other patient populations with $\mathrm{AF}$, the issue as to whether rhythm control or rate control should be pursued in HF patients with AF was studied in the Atrial Fibrillation and Congestive Heart Failure (AF-CHF) trial [30]. Rhythm control has not been found to be superior to rate control in patients with HF who develop AF subsequently, in fact, rate control was suggested as the primary approach to manage AF in HF patients [30]. It is not known, however, to what extent the possible pro-arrhythmic side effects of antiarrhythmic drugs negated the advantages of sinus rhythm maintenance in this study. Unless contraindicated, beta-adrenergic blocker drugs are recommended for ventricular rate control due to their beneficial effects on morbidity and mortality in HF patients, in combination with digoxin in case of reduced left ventricular function [31-33]. When ventricular rate control cannot be achieved by pharmacological means, atrioventricular node ablation followed by cardiac resynchronization therapy (CRT) device implantation is often performed [34-35].

In contrast, patients with $\mathrm{AF}$, where $\mathrm{HF}$ has developed as the consequence of $\mathrm{AF}$, rhythm control strategies should be chosen [33]. In HF patients with preserved systolic function, AF leads to a more severe functional class of $\mathrm{HF}$ and reduced quality of life, and to worse diastolic function compared to those in sinus rhythm [36]. In HF patients, however, the number of antiarrhythmic drugs that can be safely administered is very limited. For rhythm control of AF, Class IC compounds should be avoided in patients with structural heart disease [37], due to considerations based on the results of the Cardiac Arrhythmia Suppression Trial (CAST), where Class IC drugs increased mortality of patients with ischemic heart disease and impaired left ventricular function [38-39]. The Class IA drug quinidine increased the risk of death threefold when used in AF patients for maintenance of sinus rhythm following cardioversion [40]. Some Class III antiarrhythmic drugs are also used and have proven useful for the restoration and maintenance of sinus rhythm in patients with AF [41]. However, so far only amiodarone and dofetilide have exhibited neutral influence on mortality in patients with HF: amiodarone prevented the recurrence of AF far more effectively than propafenone and D, L-sotalol while showing no detrimental effects in patients with reduced left ventricular ejection fraction [26]. Dofetilide did not alter all-cause mortality in patients with left ventricular dysfunction but improved the conversion rate of AF to sinus rhythm in the DIAMOND-CHF trial [42]. Importantly, dofetilide improved mortality in HF patients who had normal QTc intervals before drug treatment compared to those who had a prolonged QTc [43]. D, L-sotalol should be avoided since it increases the incidence of Torsades de Pointes (TdP) arrhythmias in HF [44]. Antiarrhythmic compounds with selective $\mathrm{I}_{\mathrm{Kr}}$ blocking properties (Class III effect) markedly prolong the action potential, leading to proarrhythmic adverse effects via early afterdepolarization induction and enhancement of ventricular dispersion of repolarization, prerequisites for the development of TdP [45]. Thus, the multi-channel blocker amiodarone remains the most effective antiarrhythmic compound and the drug of choice for the majority of HF patients with AF, however, its chronic use is associated with significant extracardiac side effects [26]. Although amiodarone seems to be the least pro-arrhythmic drug among antiarrhythmic drugs administered for AF [46], it may increase sudden cardiac death risk in patients with advanced HF and with a history of previous TdP arrhythmia [47]. The majority of the extracardiac toxicity of amiodarone were hoped to be avoided with retained antiarrhythmic activity by the development of dronedarone, a newer amiodarone derivative lacking the iodine moiety, with fewer pulmonary and thyroid side effects [48-49]. The disappointing results of the PALLAS trial, however, indicated higher rates of hospitalization, heart failure episodes, stroke and all cause mortality in patients randomized to dronedarone [50-52]. Therefore, dronedarone is now rec- ommended to be used only in paroxysmal AF or following cardioversion of persistent $\mathrm{AF}$ in patients with preserved left ventricular function, and it is contraindicated to use in patients with NYHA IV class HF, and in patients with a prior episode of acute decompensation of HF, especially with left ventricular ejection fraction $<35 \%$ [53].

Atrial fibrillation carries a significant risk for thromboembolic events irrespective of the type of AF (paroxysmal, persistent or permanent) [11] and their rate increases with age [54], therefore, stroke prevention and antithrombotic therapy are major concerns for AF management. However, antithrombotic therapy in AF is not the subject of this review and the reader is referred to some excellent recent reviews and to the latest guidelines [41, 53, 55-56].

\section{Pharmacological Management of Ventricular Arrhythmias in HF}

Cardiac ventricular arrhythmias significantly contribute to morbidity and mortality in HF. However, most antiarrhythmic agents have been shown to increase mortality in patients with HF [57-58], and the proarrhythmic effects of Class I and III antiarrhythmic compounds are even more pronounced in HF patients [37-38, 40, 58]. Therefore, Class I sodium channel blocking drugs and the Class III drugs d-sotalol and dronedarone [50] should not be administered in HF, and antiarrhythmic drugs in general are listed as compounds that may worsen $\mathrm{HF}$ in the current HF management guidelines, including Class IV $\mathrm{Ca}^{2+}$ channel blockers [33]. At the time of this review, only the multi-channel blocker amiodarone and dofetilide (Class III) can be recommended for arrhythmia management in HF patients due to their neutral influence on mortality as observed in the GESICA, CHF-STAT and DIAMOND clinical trials [42, 59-61]. However, dofetilide can cause marked QT interval prolongation and can provoke $\mathrm{TdP}$, therefore dofetilide treatment initiation is a mandatory in-hospital procedure in all patients [62-63]. Due to these safety concerns dofetilide is not approved in some countries.

\section{Non-Pharmacological Arrhythmia Management in HF}

With the limited efficacy and significant safety concerns regarding antiarrhythmic drug administration for AF treatment [2627, 64], non-pharmacological approaches to AF management are steadily gaining ground and offer benefits to selected populations of patients. In approximately $10-15 \%$ of patients with AF, appropriate ventricular rate control cannot be obtained pharmacologically [65]. Radiofrequency catheter ablation of the AV node followed by implantation of a permanent pacemaker can be a solution in these cases, improving quality of life, rate control, ventricular function and exercise capacity [66]. Rhythm control by catheter ablation has been used increasingly and has been found to be superior in maintaining sinus rhythm compared to antiarrhythmic drugs [67]. The discovery of the role of pulmonary vein sleeve ectopic triggers in the development of AF [68] has led to the establishment of the pulmonary vein isolation technique [69]. This approach has been shown to be feasible in patients with AF and decreased ventricular function and heart failure, leading to an increase in ejection fraction and improvement in quality of life [70-72]. Ongoing clinical trials will provide more definitive answers on how catheter ablation and conventional therapy influences morbidity and mortality in AF patients with left ventricular ejection fraction $<35 \%$ (CASTLE_AF) [73] and whether catheter ablation of pharmacological rate or rhythm control is superior for reducing total mortality in untreated AF patients (CABANA) [74]. The success rate of nonpharmacological treatment of AF critically depends on appropriate patient selection for these procedures, summarized by the recently published expert consensus statement [75].

Sudden cardiac death due to ventricular fibrillation is a leading cause of death among HF patients [6]. However, for the treatment of venricular arrhythmias in HF, due to the significantly increased 
arrhythmia susceptibility observed in HF patients and because of the proarrhythmic adverse effects of currently available antiarrhythmic drugs, the use of pharmacological agents is very limited. Serious proarrhythmic adverse effects and increased mortality are associated with Class IA, IC and Class III antiarrhythmic drug administration in patient populations with impaired ventricular function [57-58, 76]. Among Class III agents, most likely due to its multi-channel blocking properties, amiodarone has been the most effective and relatively safe drug with the smallest proarrhythmic potential, causing TdP in approximately $1 \%$ of cases [45]. However, in patients with previous history of $\mathrm{TdP}$ amiodarone is not considered safe and should not be used [47].

The implantable cardioverter defibrillator (ICD) detects and terminates life threatening serious ventricular tachyarrhythmias and was introduced for the primary and secondary prevention of sudden cardiac death in high-risk patients including those with severe left ventricular dysfunction [77-79]. In order to compare the ability of amiodarone and single-lead, conservatively programmed ICD to reduce the risk of death from any cause, the Sudden Cardiac Death in Heart Failure Trial (SCD-HeFT) was conducted involving 2521 patients with mild to moderate heart failure [79]. The main conclusion of the trial was that in patients with left ventricular ejection fraction $\leq 35 \%$, in NYHA functional class II and III, amiodarone did not influence survival, while ICD therapy reduced the relative risk of death by any cause by $23 \%$ [79]. The authors compared their results to previous HF trials studying the effects of ICD therapy on mortality and suggested that ICD programming was critical to the final outcome. Indeed, in the Amiodarone versus Implantable Cardioverter Defibrillator (AMIOVIRT) Trial no benefit was offered by ICD therapy over amiodarone therapy, as mortality and quality of life were similar in the two groups involving 103 patients with non-ischaemic dilated cardiomyopathy, non-sustained ventricular tachycardia and with left ventricular ejection fraction $\leq 35 \%$ [80]. In the DEFINITE trial comprising 458 patients, again, no beneficial effect on all cause mortality, however, a significant reduction in arrhythmia related sudden cardiac death was observed with ICD application when compared to standard therapy with betaadrenergic blockers and ACE inhibitors in patients with severe, non-ischaemic dilated cardiomyopathy [81]. In these studies, different thresholds for pacing, different heart rate prompting, different devices (single-, dual or triple-chamber) were applied, emphasizing the importance of device settings and type selection in different subsets of patients with HF. A detailed and comprehensive review on the effectiveness of ICDs for primary prevention of sudden cardiac death has been published very recently [82].

Cardiac resynchronization therapy (CRT) devices represent one of the most promising developments for the treatment of advanced systolic HF [83-84]. It was recognized that patients with severe heart failure frequently had myocardial regions with delayed activation and contraction resulting in dyssynchrony and these alterations influenced mortality and conduction delay was a prognostic marker in patients with heart failure [85]. Cardiac resynchronization therapy aims at the synchronization of electrical activation of the left and right sides of the heart thereby improving cardiac output [8687]. CRT therapy is now indicated in HF patients with NYHA class II to IV symptoms in spite of adequate therapy, left ventricular ejection fraction $\leq 35 \%$ and QRS width $\geq 120 \mathrm{~ms}$ [88]. Cardiac resynchronization therapy has been found to reduce mortality and to promote reverse left ventricular remodeling as well as to improve quality of life [89] and these beneficial effects were maintained during long term follow-up [90]. Similar results were observed in patients with moderate (NYHA class II) heart failure [91] and even mild, NYHA class I heart failure, although risks should be weighed carefully against benefits in this group of patients [92]. The effect of CRT therapy on arrhythmias is not fully elucidated. Previously it was accepted that CRT did not decrease AF incidence [93], however, some studies suggest that CRT is associated with increased resumption of sinus rhythm in patients with persistent AF [94] and even permanent AF [95-96]. Although some case reports described CRT provoking ventricular arrhythmias [97-98], others reported that CRT reduced the burden of ventricular arrhythmias [99], and the analysis of two large CRT trials did not find an increase in polymorhic VT or a decrease in monomorphic VT in 880 patients receiving CRT therapy [100]. Cardiac resynchronization and ICD therapies are frequently combined as cardiac resynchronization therapy with a defibrillator (CRT-D) [88, 101]. Upgrading ICD therapy to CRT-D therapy in HF patients due to worsening of symptoms can significantly reduce the frequency of ventricular tachycardia, fibrillation and device shocks [102].

It should be noted that cardiac electronic device implantations are not without complications, moreover, a higher than expected complication risk was identified in a Danish study involving almost 6000 patients receiving permanent pacemakers, ICDs, CRT and CRT-D devices, at almost $10 \%$ of patients experiencing at least one complication $[79,103]$. A particularly troublesome complication of CRT device implantation is the markedly increased risk of infection that can be difficult to manage and is associated with significant morbidity [104].

Not all patients who are candidates for CRT respond to therapy, and the exact correlation between QRS widening and developing dys-synchrony needs to be further evaluated, the use of CRT in patients with $\mathrm{AF}$ is a subject to controversy $[9,105]$. In HF patients with reduced ejection fraction, recurrent ventricular arrhythmias and ICD shocks are observed, leading to significant morbidity and mortality as well as reduced quality of life (for a recent review see [106]). Optimal programming of ICD decreases the number of shocks [107], and ICD application reduces sudden cardiac death [82], however, these devices do not reduce ventricular arrhythmia incidence in HF patients. For the management of recurrent arrhythmias and reduction of ICD shocks in HF patients with reduced ejection fraction and ICD, adjuvant antiarrhythmic therapy is warranted. In this regard, amiodarone has been found to be most effective for ventricular arrhythmia treatment and shock reduction. However, the use of amiodarone is limited by serious extracardiac adverse effects [108].

\section{Need for New, Safer and More Efficacious Antiarrhythmic Compounds}

Based on the overview above, there is a clear unmet need for novel antiarrhythmic drugs for the treatment of atrial fibrillation and serious ventricular arrhythmias in HF patients, that are safer and more efficacious compared to currently available compounds. Some promising new drugs, like tedisamil, azimilide, dronedarone and vernakalant have not fulfilled expectations for pharmacological atrial and/or ventricular arrhythmia management in the setting of heart failure with reduced left ventricular function.

In the following part of this review, some of the main aspects and mechanisms of the increased arrhythmia susceptibility observed in HF are described, followed by the discussion of novel and promising targets and investigational compounds for antiarrhythmic intervention in $\mathrm{HF}$

\section{MYOCARDIAL REMODELING: CREATING AR- RHYTHMIA SUBSTRATE AND TRIGGERS IN HEART FAILURE}

In an attempt to maintain proper cardiac function and intracellular homeostasis and in response to pathophysiological processes involved in cardiovascular diseases, including HF and AF development, a number of electrophysiological and structural changes are observed in the heart, collectively described as myocardial remodeling. These alterations are partly adaptive in nature, however, when maintained for longer periods they can lead to further deterioration of cardiac function, and importantly, can significantly contribute to arrhythmia development and maintenance. This review 
mainly focuses on the arrhythmogenic consequences of electrical remodeling and their possible exploitation for therapy, thus the reader is recommended to refer to previous articles discussing structural remodeling [109-110]. The following sections will deal with three main areas of electrical remodeling in $\mathrm{HF}$ and $\mathrm{AF}$ : aspects of myocardial repolarization, conduction and impulse generation remodeling.

\section{Remodeling of Atrial and Ventricular Action Potential and Repolarization in $\mathrm{AF}$ and $\mathrm{HF}$}

The cardiac action potential is a highly regulated and coordinated function of different inward and outward ionic currents and exchangers ensuring proper electrical and electromechanical function of different regions of the heart [111-112]. In a number of pathological settings, including heart failure and atrial fibrillation, fundamental changes appear in the duration and shape of the action potential. Some of these changes are adaptive: it is consistently found that action potential duration is prolonged in HF [113-115] and it may serve to compensate for impaired $\mathrm{Ca}^{2+}$ transients and reduced contractility in failing cardiac myocytes by increasing $\mathrm{Ca}^{2+}$ load and subsequent release thereby improving cell contractility (Fig. 1).

Excessive prolongation of repolarization, however, can lead to the development of early afterdepolarizations (EADs) $[115,117]$ mainly due to recovery of $\mathrm{I}_{\mathrm{Ca}, \mathrm{L}}$ from inactivation [118]. EADs can provoke Torsades de Pointes polymorphic ventricular tachycardia (TdP) in HF patients [119]. TdP leads to syncope and often reverts back to sinus rhythm spontaneously, however, TdP can degenerate into ventricular fibrillation that leads to sudden cardiac death without intervention [118]. Action potential prolongation in HF is due to the remodeling of ion channels carrying inward and outward ionic currents.

Changes in inward currents include the increase of the slowly inactivating, late sodium current $\left(\mathrm{I}_{\mathrm{Na}}\right.$, late $)$ that contributes to APD

(A)

Normal heart
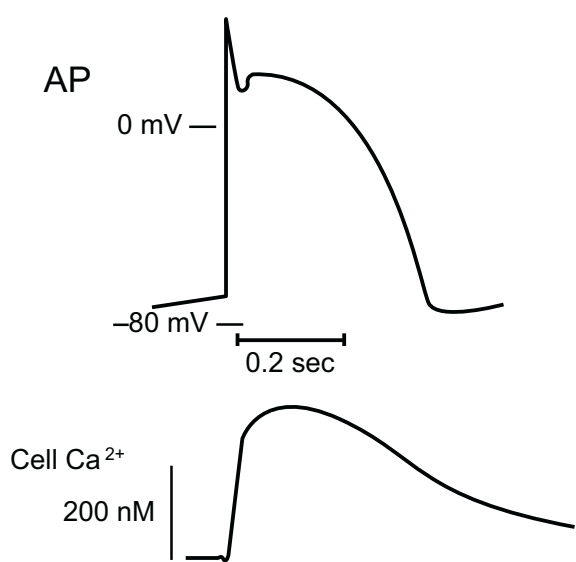

Cell contraction

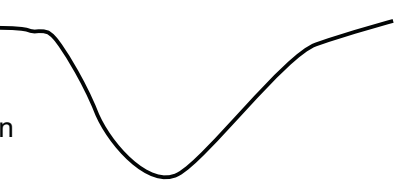

prolongation and arrhythmogenesis in HF [120-122]. Intracellular calcium handling is significantly influenced by HF on several levels. The L-type calcium current $\left(\mathrm{I}_{\mathrm{Ca}, \mathrm{L}}\right)$ has been mainly reported to be unchanged in experimental HF models and humans [123-125] or decreased in humans [126]. However, sarcoplasmic reticulum (SR) $\mathrm{Ca}^{2+}$ ATPase (SERCA) is downregulated, contributing to decreased $\mathrm{SR} \mathrm{Ca}^{2+}$ content and increased diastolic $\mathrm{Ca}^{2+}$ concentration [127]. The decreased SERCA function impairs $\mathrm{Ca}^{2+}$ removal from the cytoplasm and may be the cause for the observed $\mathrm{Na}^{+}-\mathrm{Ca}^{2+}$ exchanger (NCX) upregulation in HF [128]. The electrogenic NCX exchanges $3 \mathrm{Na}^{+}$for one $\mathrm{Ca}^{2+}$ through the plasma membrane and its main function is the removal of excess intracellular $\mathrm{Ca}^{2+}$ during diastole, however, the exchanger can work in both forward $\left(\mathrm{Ca}^{2+}\right.$ extrusion) and reverse $\left(\mathrm{Ca}^{2+}\right.$-influx $)$ modes, depending on actual membrane potential, intracellular and extracellular $\mathrm{Na}^{+}$and $\mathrm{Ca}^{2+}$ concentrations [129]. Since the NCX is responsible for net inward current during the later phase of the action potential, its upregulation may importantly contribute to APD prolongation and arrhythmogenic delayed afterdepolarization (DAD) development in $\mathrm{HF}$ [130].

Electrical remodeling includes profound changes in voltagegated potassium channel expression in HF. Although experimental animal and human studies show some differences, the most consistent changes are downregulation of the transient outward current $\left(\mathrm{I}_{\mathrm{to}}\right)[123,131]$, the slowly activating component of the delayed rectifier $\left(\mathrm{I}_{\mathrm{Ks}}\right)[117,125,132]$ and inward rectifier $\left(\mathrm{I}_{\mathrm{K} 1}\right)[117,133]$, while with the rapid component of the delayed rectifier $\left(\mathrm{I}_{\mathrm{Kr}}\right)$ most studies reported no changes [117, 125, 132].

Therefore, in HF, the repolarization capacity of ventricular myocytes is significantly reduced due to the downregulation of different repolarizing $\mathrm{K}^{+}$channels and increased $\mathrm{I}_{\mathrm{Na}}$, late, promoting $\mathrm{EAD}$ and/or DAD formation and arrhythmia generation, as described above. Also, decreased repolarization capacity means that repolarization reserve [134] is markedly impaired in failing ventricular myocytes. Repolarization reserve refers to the backup

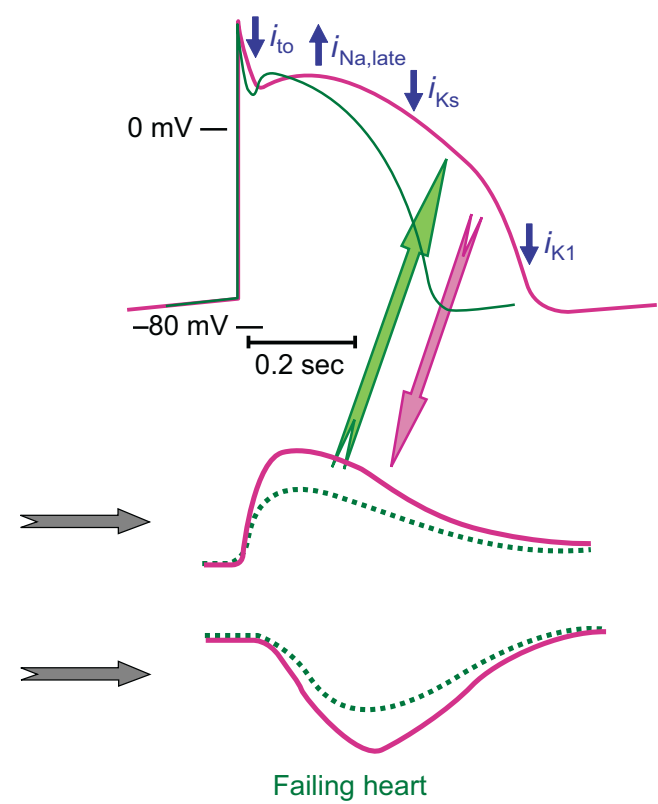

(B)

Fig. (1). Schematic illustration of action potentials, $\mathrm{Ca}^{2+}$ transients and cell shortening (contraction) from normal (A) and failing (B) cardiomyocytes showing the compensatory changes in action potential duration by electrical remodeling (indicated by violet lines) in HF. Arrows indicate changes in current densities. Reproduced with permission from [116]. 
mechanisms of repolarization in the heart, namely the decreased function (by congenital or acquired means) of a repolarizing current can be compensated for by an increase in other potassium currents [135-136]. Impaired repolarization reserve importantly contributes to increased arrhythmia susceptibility in HF patients. In clinical practical terms it means that not only antiarrhythmic drugs with strong potassium channel blocking properties (Class IA, IB and Class III) can provoke TdP, VF and sudden cardiac death in HF patients, but the application of non-cardiovascular drugs that possess weaker $\mathrm{K}^{+}$current inhibitory effects, including some antibiotics [137], antimycotics [138], antihistamines [139], antipsychotics [140], NSAIDs [141], even dietary constituents [142], $\mathrm{K}^{+}$-losing diuretics etc., can further interfere with repolarization [143] and can lead to unexpected and serious ventricular arrhythmia development in this patient population. Importantly, the presence of repolarization prolonging genetic mutations responsible for different forms of long QT (LQT) syndromes can also exacerbate ventricular arrhythmias in HF.

In clinical and experimental settings, the longer AF persists, the harder it becomes to convert AF back to sinus rhythm. This phenomenon was first described by Allessie and colleagues with the now famous expression: "atrial fibrillation begets atrial fibrillation", in their work based on a goat model of AF [144]. The longer $\mathrm{AF}$ is present, the more pronounced changes appear in atrial myocardial structure, electrophysiology and function (Fig. 2).

As (Fig. 3) illustrates, in contrast to the ventricular AP changes in $\mathrm{HF}$, atrial fibrillation associated remodeling of the atria results in atrial AP shortening and triangulation [145], that leads to shortened atrial effective refractory period and creation of an arrhythmia substrate that is responsible for further maintenance of AF.

Again, the remodeling of the AP, at least in part, is the result of compensatory changes in atrial ion channel expression and function. Rapid atrial rates during AF lead to $\mathrm{Ca}^{2+}$ overload of atrial myocytes [146-147], and the consistent finding of reduced $\mathrm{I}_{\mathrm{Ca}, \mathrm{L}}$ [148] that protects the cells from this $\mathrm{Ca}^{2+}$ overload and also contributes to APD and refractoriness abbreviation [149-150]. These protective changes, however, become detrimental over longer periods of time since the shortened APD and refractoriness makes the atria more vulnerable to AF initiation and favours the maintenance of the arrhythmia [144].
Only small, about 10 to $20 \%$ changes in $\mathrm{I}_{\mathrm{Na}}$ density in atrial myocytes of patients with chronic AF have been detected [151152]. In atrial tachycardia induced AF animal models, however, a marked decrease in $\mathrm{I}_{\mathrm{Na}}$ was observed [153]. Decreased $\mathrm{I}_{\mathrm{Na}}$ can slow atrial conduction and may further shorten wavelength [153] already abbreviated by APD and refractoriness shortening, and a shorter wavelength increases the number of atrial re-entry circuits [154]. Some in vitro animal experimental data also suggests that an increased $\mathrm{I}_{\mathrm{Na}}$, late might play a role in atrial arrhythmia generation [155]. Data regarding NCX expression are inconsistent: a significant increase in protein expression [156] and no change in NCX mRNA have been both described in AF [157]. Voltage-gated potassium currents exhibit significant changes as part of the electrical remodeling in the atria, including an approximately $60 \%$ decrease in $\mathrm{I}_{\text {to }}[149,151]$, a decrease in the atrial specific acetylcholineactivated $\mathrm{K}^{+}$channel $\left(\mathrm{I}_{\mathrm{K}, \mathrm{ACh}}\right)$ expression [158], but an increased constitutively active (without cholinergic ligand stimulation) $\mathrm{I}_{\mathrm{K}, \mathrm{ACh}}$ component [159], however, $\mathrm{I}_{\mathrm{K} 1}$ upregulation is consistently present in patients with AF [160]. The increases in $\mathrm{I}_{\mathrm{K} 1}$ and constitutive $\mathrm{I}_{\mathrm{K}, \mathrm{ACh}}$ make the membrane potential more hyperpolarized and shorten the APD, therefore contributing to re-entry rotor stabilization [161]. Experimental animal data suggest that $I_{K r}$ and $I_{K s}$ are unaltered [162], and the sparse functional data from humans indicated increased $\mathrm{I}_{\mathrm{Ks}}$ [163]. The atrial specific ultrarapidly activating $\mathrm{I}_{\text {Kur }}[164]$ expression may be either decreased $[163,165]$, or unaltered [149, 151]. Importantly, if $\mathrm{I}_{\mathrm{Kur}}$ expression/activity is decreased this could potentially hinder the further development of the numerous $\mathrm{I}_{\mathrm{Kur}}$ inhibitory compounds that have been developed for the atrial specific treatment of AF [166-167]. Cardiac ATP-sensitive potassium channels $\left(\mathrm{K}_{\mathrm{ATP}}\right)$ [168] are voltage-independent potassium channels linking cell metabolism to membrane excitability, they are predominantly closed under normoxic conditions and are opened by hypoxia and metabolic stress such as elevated workload [169], considerably shortening the action potential. $\mathrm{K}_{\text {ATP }}$ channels are responsible for the activation of several cardioprotective mechanisms [170]. Studies on expression of $\mathrm{K}_{\mathrm{ATP}}$ in AF are inconclusive, with some studies showing no change, increase or decrease in expression [158, 171-172]. Furthermore, while expression of $\mathrm{K}_{\mathrm{ATP}}$ channels may be unaffected, as increased workload may activate $K_{\text {ATP }}$ channels, the relative activity of these channels may actually be increased in HF and/or AF. However, this remains to be
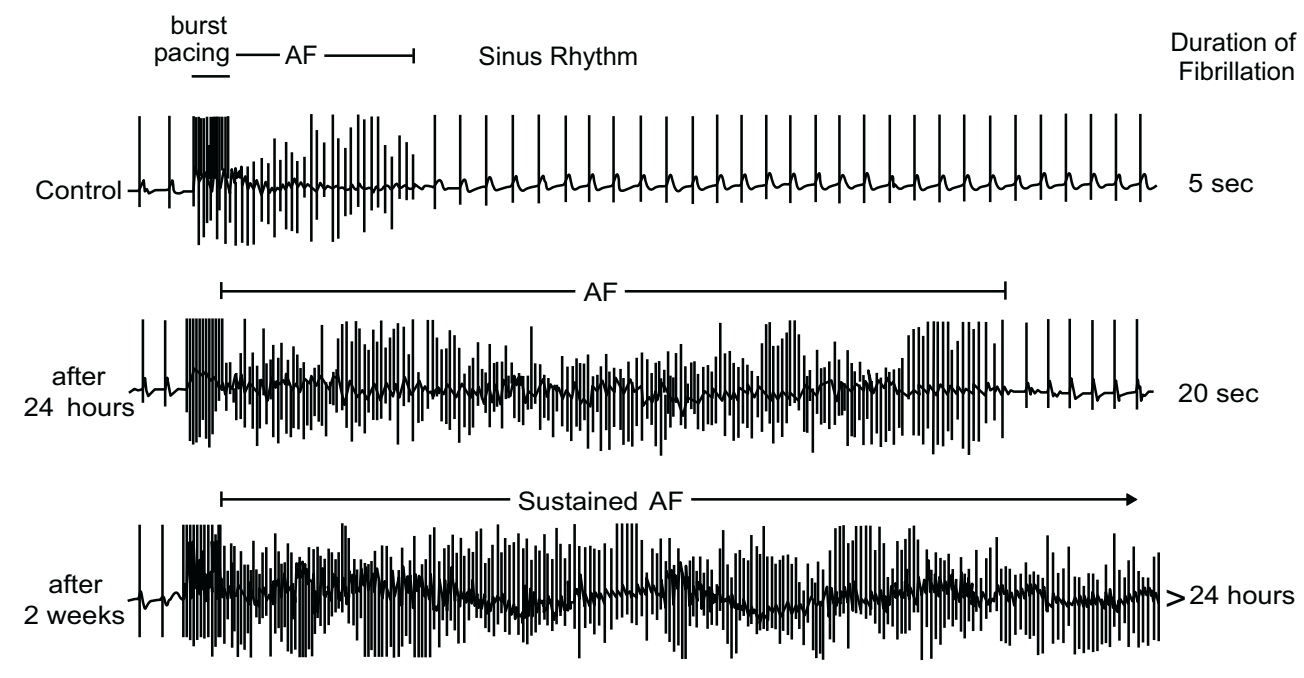

2 sec

Fig. (2). Representative atrial electrograms recorded from a chronically instrumented goat. The duration of burst-induced AF episodes were prolonged when preceding AF was maintained for longer time periods ( $24 \mathrm{~h}$ and then 2 weeks). Upper trace: before the burst, the goat was in sinus rhythm and the induced AF terminated in 5 seconds. Middle trace: The burst induced AF terminated in 20 seconds after $24 \mathrm{~h}$ preceding AF. Bottom trace: Burst induced AF did not terminate when the preceding AF lasted for 2 weeks. Reproduced from [144] with permission. 

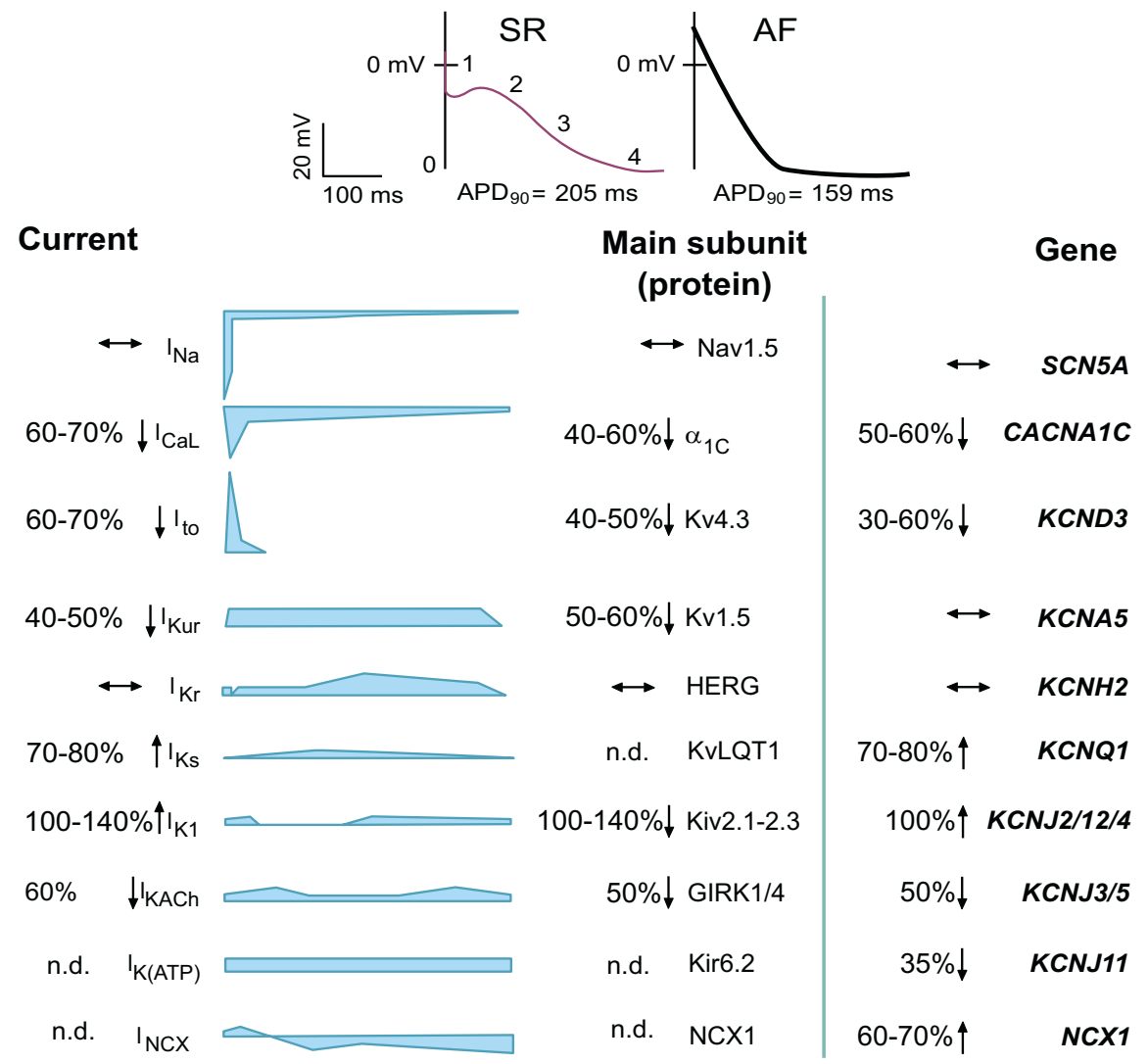

Fig. (3). Remodeling of the atrial action potential and the underlying alterations of ionic currents and channel subunit expression changes. SR: sinus rhythm; AF: atrial fibrillation. Please see text for detailed discussion on elements of atrial electrical remodeling in AF. Reproduced from [110] with permission.

determined conclusively. Moreover, several cardiac $\mathrm{K}_{\text {ATP }}$ channel subunit mutations have been found to underlie some rare congenital forms of idiopathic AF [173]. Therefore, $\mathrm{K}_{\mathrm{ATP}}$ channels may play a role in the development and/or maintenance of $\mathrm{AF}$ in $\mathrm{HF}$, where continuously elevated adrenergic stimulation, increased workload and myocardial ischaemia are common features of these diseases.

\section{Remodeling of Conduction in AF and HF}

Conduction abnormalities are important contributors to increased arrhythmia susceptibility and creation of an arrhythmia substrate in both HF and AF. Indeed, as already mentioned, reduced intraventricular conduction is prognostic for heart failure [85]. Impairment of gap junction function has been found in different forms of human cardiomyopathies and HF [174], mostly attributed to downregulation and altered distribution of ventricular gap junction constituent connexin43 (Cx43) [175-177]. These changes are further exacerbated by ischaemia increasing the chance for the development of serious ventricular arrhythmias and sudden cardiac death [178]. While increased expression of $\mathrm{Cx} 40$ and its lateralization is observed in $\mathrm{AF}$, data regarding $\mathrm{Cx} 43$ expression and localization are not conclusive, probably due to different patient populations studied [179-180]. Interestingly, in a recent human study, the application of the beta-adrenergic blocker metoprolol has been found to antagonize the detrimental changes in $\mathrm{Cx} 43$ localization and subsequent conduction changes in patients with AF [181]. The detailed discussion of this topic is beyond the scope of this paper and readers are referred to a comprehensive review on this topic published in this issue [182].

\section{Remodeling Leading to Increased Triggered Activity}

In addition to increased arrhythmia susceptibility by the development of arrhythmia substrates due to pathological changes in repolarization and conduction in $\mathrm{HF}$ and $\mathrm{AF}$, an arrhythmogenic trigger is required for arrhythmia induction. The hyperpolarizationactivated, cyclic nucleotide-gated pacemaker "funny current" $\left(I_{f}\right)$, encoded by the HCN genes, plays a key role in sinus node pacemaking [183]. Increased expression of HCN2 and HCN4 in human ventricular myocytes from HF hearts may contribute to the generation of abnormal ventricular-triggered activity in HF [184-185]. Increased $\mathrm{HCN}$ subunit expression has been found also in the atria of the failing heart, and increased $\mathrm{I}_{\mathrm{f}}$ in atrial tissue may contribute to abnormal ectopic activity in AF [186]. Pulmonary vein foci have been identified as sources of initial triggered activity in AF [68, 187], leading to the development of electrical isolation of these pulmonary vein muscle sleeves via catheter ablation. Remodeling affecting the ryanodine receptors, SERCA and NCX also play important roles in the development of arrhythmic triggers in HF [188192] and AF [193-195], and the reader is referred to excellent reviews on these topics in the current issue [196-197].

Contribution of Myocardial Ischaemia and Ischaemia-Induced Remodeling to the Development of Arrhythmias in Heart Failure

Myocardial ischaemia and infarction can both cause and be a consequence of $\mathrm{HF}$ and $\mathrm{AF}$, and contribute to arrhythmogenic electrophysiological changes and remodeling via their own distinct mechanisms $[20,198]$. These mechanisms include increased dispersion of repolarization between regions with different degrees of ischaemia and different degree of activation of $\mathrm{K}_{\mathrm{ATP}}$ channels [198201], impairment of conduction in early ischaemia [202], significantly different remodeling of repolarization and conduction in non-infarcted versus infarction border zone tissues [20], potassium loss from ischaemic cardiac tissue leading to heterogenous membrane potential depolarization of tissues with varying degree of 
ischaemia [203-204]. These electrical and structural changes can add to the already complex alterations present due to $\mathrm{HF}$ and/or AF.

\section{NOVEL PHARMACOLOGICAL APPROACHES FOR THE TREATMENT OF ARRHYTHMIAS IN HEART FAIL- URE}

In the final part of this review, the possible antiarrhythmic pharmacological modulation of selected promising targets identified by $\mathrm{HF}$ and $\mathrm{AF}$ induced remodeling studies are discussed.

\section{$\mathbf{I}_{\mathrm{Na} \text {, late }}$ Inhibitors}

In addition to the rapidly inactivated component of the $\mathrm{Na}_{\mathrm{V}} 1.5$ carried, SCN5A gene encoded human voltage dependent peak sodium current $\left(\mathrm{I}_{\mathrm{Na}}\right)$, that is responsible for the fast upstroke of the cardiac action potential and impulse propagation in the myocardium, a slowly inactivating sodium current component has been identified that persists through the action potential plateau [205206]. The late sodium current $\left(\mathrm{I}_{\mathrm{Na}}\right.$, late $)$ has an amplitude 100 fold smaller compared to the peak $\mathrm{Na}^{+}$current, however, it may contribute to the plateau phase of the AP and to dispersion of APD in the myocardium [207]. Increased $\mathrm{I}_{\mathrm{Na}}$, ate has been observed in several cardiovascular diseases, including myocardial ischaemia, angina pectoris, congenital long QT syndrome, HF and AF [208-211]. In the ventricle, increased $\mathrm{I}_{\mathrm{Na}}$, late prolongs the action potential duration $[205,209,212]$ and facilitates EAD generation [212-213], while in guinea pig atrial myocytes it was shown to play a role in DAD formation and sustained triggered activity [155]. Therefore, the inhibition of the $\mathrm{I}_{\mathrm{Na}}$, late current has been proposed as a promising new approach for the treatment of ventricular arrhythmias in HF as well as AF management [214-215]. However, any novel compound developed against this target needs to show considerable selectivity for the inhibition of $\mathrm{I}_{\mathrm{Na}}$, late as opposed to peak $\mathrm{I}_{\mathrm{Na}}$ inhibition to avoid adverse effects on myocardial conduction and contractility, i.e. to be useful in patients with reduced ventricular function and/or structural heart disease. Interestingly, amiodarone, the most effective antiarrhythmic multichannel blocker drug exhibited a 13-fold more potent inhibitory effect on $\mathrm{I}_{\mathrm{Na}}$, late than on peak $\mathrm{I}_{\mathrm{Na}}$ [216]. Resveratrol, a red wine polyphenol with cardioprotective characteristics [217] has been shown to possess a 2-fold selectivity for late over peak $\mathrm{I}_{\mathrm{Na}}$ inhibition [218]. Ranolazine, a $\mathrm{I}_{\mathrm{Na}}$, late blocker approved for the treatment of angina pectoris [219], is considered to have a 30 to 40 -fold higher $\mathrm{I}_{\mathrm{Na}}$, late inhibitory potency over peak $\mathrm{I}_{\mathrm{Na}}$ [220]. However, in canine and human cardiac preparations, ranolazine significantly and use-dependently decreased the maximum rate of depolarization $\left(\mathrm{V}_{\max }\right)$ at a concentration of $10 \mu \mathrm{M}$, suggesting a peak $\mathrm{I}_{\mathrm{Na}}$ inhibiting effect with Class $\mathrm{I} / \mathrm{B}$ antiarrhythmic characteristics in concentrations previously considered to be selective for $\mathrm{I}_{\mathrm{Na}}$, late inhibition [221]. In guinea pig ventricular myocytes, ranolazine inhibited the increase of $\mathrm{I}_{\mathrm{Na}}$, late induced by sea anemone toxin ATX-II administration [222]. In left ventricular myocytes from failing dog hearts, ranolazine reversed abnormalities of repolarization and contractile dysfunction [223]. Recently, ranolazine has been shown to reduce the $\mathrm{I}_{\mathrm{Kr}}$ blocker dofetilide induced TdP in dogs with chronic atrioventricular block [224], a large animal proarrhythmia model featuring impaired repolarization reserve due to downregulation of $\mathrm{I}_{\mathrm{Ks}}$ [225]. It should be noted that ranolazine also blocks $\mathrm{I}_{\mathrm{Kr}}$ [226], however, its blocking effect is not frequency dependent and recovery from this block is fast [227]. Thus, the antiarrhythmic effects of ranolazine were attributed to $I_{N a}$, late inhibition rather than $I_{K r}$ block, and the net effect of the drug on the APD was considered to depend on the magnitudes of $\mathrm{I}_{\mathrm{Na}}$, late and $\mathrm{I}_{\mathrm{Kr}}$ in the given situation. Ranolazine was shown to cause a slight prolongation of the QT interval in patients [228]. In a recent paper in a Langendorff-perfused normal rabbit heart model (without increased $\mathrm{I}_{\mathrm{Na}}$, late $) 10 \mu \mathrm{M}$ ranolazine further increased d-sotalol induced action potential duration prolongation, however, the compound also reduced the incidence of dsotalol and low potassium concentration-induced TdP [229]. These results strongly suggest that ranolazine has additional electrophysi- ological effects that may prove to be beneficial or even detrimental (further prolongation of repolarization) in certain clinical settings. Therefore, compounds with more selective $\mathrm{I}_{\mathrm{Na}}$, late over peak $\mathrm{I}_{\mathrm{Na}}$ effects are desirable and preferably devoid of $\mathrm{I}_{\mathrm{Kr}}$ blocking properties to prevent ventricular pro-arrhythmic adverse effects in patients with $\mathrm{HF}$ and/or diseases impairing ventricular repolarization reserve. In this regard, a novel, highly selective $\mathrm{I}_{\mathrm{Na}}$, late inhibitor (100fold more potent late current than peak current inhibition), GS458967 (GS967; Fig. 4) was synthesized, that did not affect other currents [230] and exhibited protective effects against experimental ventricular and atrial arrhythmias [231-232]. In a very recent publication, a novel small molecule targeting multiple mechanisms involved in atrial fibrillation showed a 3 -fold higher $\mathrm{I}_{\mathrm{Na}}$, late inhibition over peak $\mathrm{I}_{\mathrm{Na}}$ inhibition, in addition to other ion channel blocking properties, and exhibited efficacy against AF in a chronic atrial tachypacing induced AF dog model [233]. Another novel $\mathrm{I}_{\mathrm{Na}}$, late inhibitor, F 15845, reduced the incidence of coronary artery ligation induced arrhythmias in rats [234]. Based on these data, inhibition of $\mathrm{I}_{\mathrm{Na}}$, late represents a promising approach for the treatment of both ventricular and atrial arrhythmias in HF. A more detailed discussion of the pathological consequences of increased $\mathrm{I}_{\mathrm{Na} \text {, late }}$ and the potential antiarrhythmic applications of $\mathrm{I}_{\mathrm{Na}}$, late blockers is the subject of a pertinent paper in this issue [235].

\section{Potassium Channel Activators}

As already discussed, APD prolongation is a consistent finding in ventricular myocytes from failing animal and human hearts [124], and repolarization prolongation is a major cause of serious ventricular arrhythmias and sudden cardiac death in HF [236]. Furthermore, increased spatial dispersion of repolarization due to nonuniform APD prolongation, an important contributor to the creation of an arrhythmia substrate was found in HF and cardiac hypertrophy [237], that can be further exacerbated by $\mathrm{K}^{+}$channel blocking drugs in these patients due to the different regional and transmural distribution of expression of these channels. In theory, there are several approaches that can be utilized to limit excessive AP prolongation in congenital and acquired long QT via the activation of different voltage dependent potassium channels. Below, the effects of novel compounds developed for the pharmacological activation of $\mathrm{I}_{\mathrm{Kr}}, \mathrm{I}_{\mathrm{Ks}}$ and $\mathrm{I}_{\mathrm{to}}$ are discussed.

Pharmacological activators of $\mathrm{I}_{\mathrm{Kr}}$ have been the most intensively studied among voltage gated $\mathrm{K}^{+}$channel activators so far. A number of $\mathrm{I}_{\mathrm{Kr}}$ activators have been developed by different companies in recent years (Fig. 5) [238-240]. NS1643 and NS3623 (by NeuroSearch) influence hERG1 inactivation, both causing a rightward shift on the inactivation curve of the current [238, 241]. It is important to note that NS1643 blocks $\mathrm{I}_{\mathrm{Ks}}$ too, albeit only at slow pacing rates [242]. Since $\mathrm{I}_{\mathrm{Ks}}$ plays a critical role in cardiac ventricular repolarization reserve [243], it is not yet clear how this effect influences the antiarrhythmic activity of NS1643. Another hERG1 channel agonist, RPR260243 (by Sanofi-Aventis), influences channel deactivation properties [239] and also causes a rightward shift on the inactivation curve of the current [244], similarly to the NS hERG1 activator compounds. Additional hERG1 activator compounds were developed by Pfizer, PD-118057 and PD-307243 [240], and the latter has been shown to slow both deactivation and inactivation of the channel. ICA-105574 was developed by Icagen (later acquired by Pfizer) and was shown to be a potent inhibitor of hERG channel inactivation and to shorten action potentials in guinea pig ventricular cardiomyocytes [245]. A very recent study compared the effects of NS1643 and ICA-105574 in guinea pig preparations and found that both compounds shortened action potentials in isolated ventricular cardiomyocytes and QT intervals in isolated hearts, however, only ICA-105574 prevented $\mathrm{I}_{\mathrm{Kr}}$ and $\mathrm{I}_{\mathrm{Ks}}$ inhibitor induced arrhythmias in isolated hearts [246]. Importantly, ICA-105574 exhibited proarrhythmic adverse effects in normal hearts when applied in higher concentrations in the same study. Although NS1643 did not show antiarrhythmic effects in isolated 
<smiles>COc1ccccc1OCC(O)CN1CCN(CC(=O)Nc2c(C)cccc2C)CC1</smiles>

ranolazine<smiles>FC(F)(F)Oc1ccc(-c2ccc3nnc(C(F)(F)F)n3c2)cc1</smiles>

GS967<smiles>COc1ccccc1SC[C@H](C)CN[C@@H]1COc2ccccc2SC1</smiles>

F-15845

Fig. (4). Chemical structures of representative $I_{\mathrm{Na}}$ late blockers.<smiles>O=C(Nc1cc(C(F)(F)F)ccc1O)Nc1cc(C(F)(F)F)ccc1O</smiles>

NS-1643<smiles>COc1ccc2nccc(C(=O)CCC3CCN(CC#Cc4cc(F)cc(F)c4F)CC3C(=O)O)c2c1</smiles>

RPR260243<smiles>O=C(Nc1ccc(Oc2ccccc2)cc1)c1cccc([N+](=O)[O-])c1</smiles>

ICA-105574<smiles>O=C(O)c1ccccc1Nc1ccc(CCc2ccc(Cl)c(Cl)c2)cc1</smiles>

PD-118057

Fig. (5). Chemical structures of representative $I_{K r}$ activators.

guinea pig hearts [246], in isolated guinea pig ventricular cardiomyocytes NS1643 prevented triggering activity due to early afterdepolarizations [242]. NS1643 convincingly exhibited antiarrhythmic activity in two different rabbit models of TdP [247]: in rabbits with chronic atrioventricular block and bradycardia [248], and in the classical methoxamine-sensitized rabbit model [249]. In a transgenic rabbit model of congenital LQT1 syndrome, NS1643 significantly shortened the QTc interval, however, it increased the incidence of arrhythmias in this model and the proarrhythmic effect was attributed to the excessive repolarization shortening in these animals [250]. NS3623 shortened the QTc interval in anesthetized and conscious guinea-pigs, and reversed QTc prolongation induced by the $\mathrm{I}_{\mathrm{Kr}}$ blocker E-4031 [251]. Interestingly, NS3623 impaired conduction in optical mapping experiments in Langendorff- perfused guinea-pig hearts, however, the authors found that di-4ANEPPS, the voltage sensitive dye itself decreased conduction velocity, raising the possibly of confounding these results [252].

The slow component of the delayed rectifier potassium current, $\mathrm{I}_{\mathrm{Ks}}$, plays a critical role in cardiac ventricular repolarization reserve $[136,243,253]$, and its downregulation has been confirmed in animal models of HF and cardiac hypertrophy as well as in human HF $[20,117,125,132,225]$. Its pharmacological activation could be used for increasing repolarization reserve and for the prevention of excessive prolongation of action potentials at slow heart rates in clinical settings associated with $\mathrm{I}_{\mathrm{Ks}}$ downregulation and/or dysfunction. Surprisingly, few compounds have been developed for this purpose and very few studies have investigated the effect of $\mathrm{I}_{\mathrm{Ks}}$ activators on repolarization. An $\mathrm{I}_{\mathrm{Ks}}$ activator, L-364, 373 (Fig. 6) 


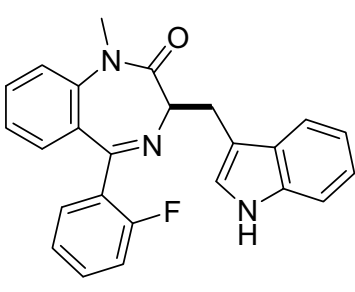

L-364,373<smiles>O=C(Nc1cc(C(F)(F)F)cc(C(F)(F)F)c1)Nc1c(Br)cc(Br)cc1-c1nnn[nH]1</smiles>

NS-5806

Fig. (6). Chemical structure of the $\mathrm{I}_{\mathrm{Ks}}$ activator L-364, 373 and $\mathrm{I}_{\text {to }}$ activator NS5806.

developed more than 15 years ago [254] was shown to enhance $\mathrm{I}_{\mathrm{Ks}}$ by causing a negative shift in the voltage dependence of channel activation and by slowing channel deactivation [255]. The shortening of the APD was observed in control, hypertrophied and dofetilide $\left(\mathrm{I}_{\mathrm{Kr}}\right.$ blocker) treated rabbit ventricular myocytes accompanied by EAD elimination in hypertrophied cardiomyocytes in the same study. Some investigators failed to find any $\mathrm{I}_{\mathrm{Ks}}$ activating effect of this compound [256], while others found the drug rescued repolarization in a guinea-pig cellular model of LQT2 syndrome [257]. However, according to the results of a recent study, the two enantiomers of L-364, 373 had opposing effects on $\mathrm{I}_{\mathrm{Ks}}$, explaining why the racemic drug was devoid of any $\mathrm{I}_{\mathrm{Ks}}$ activating effect in other studies [258]. In order to properly investigate the putative beneficial effect of $I_{K s}$ activation in pathological settings with impaired repolarization reserve and arrhythmogenesis, additional $\mathrm{I}_{\mathrm{Ks}}$ activator compounds need to be studied in different models of congenital and acquired models of prolonged repolarization. Importantly, further elucidation of the roles and tissue distribution of different KCNQ1 channel complexes formed with different regulatory $\beta$-subunits are needed before meaningful cardiac selective $\mathrm{I}_{\mathrm{Ks}}$ activator development becomes feasible [259].

As discussed earlier, HF associated electrical remodeling involves the downregulation of different potassium channels responsible for repolarization, including $\mathrm{I}_{\text {to }}$ [20]. Impairment of the early phase of repolarization governed by $\mathrm{I}_{\text {to }}$ can lead to pathological alterations in calcium homeostasis, reduced calcium-induced calcium release and reduced contractility [260]. Therefore, the pharmacological activation of $\mathrm{I}_{\text {to }}$ may be a suitable target for improving calcium homeostasis and increasing contractility in HF. A recently developed $\mathrm{I}_{\text {to }}$ activator, NS5806 (Fig. 6) increased $\mathrm{I}_{\text {to }}$ by $80 \%$ in canine epicardial right ventricular cells, only by $16 \%$ in endocardial cells, and increased peak $\mathrm{I}_{\text {to }}$ in atrial myocytes by $25 \%$ [261]. Importantly, in the same study NS5806 was found to strongly inhibit atrial $\mathrm{I}_{\mathrm{Na}}$, while the compound had little effect on ventricular $\mathrm{I}_{\mathrm{Na}}$ [261]. The antianginal and $\mathrm{I}_{\mathrm{Na}}$, late inhibitor ranolazine exhibited efficacy against AF and this effect was attributed to its atrial selective $\mathrm{I}_{\mathrm{Na}}$ blocking properties [262]. Therefore, it would be very interesting to see whether NS5806 had any beneficial effect in an animal model of atrial fibrillation. In a canine model of rapid ventricular pacing induced heart failure, where reduced $\mathrm{I}_{\text {to }}$ density, slowed recovery of $I_{t o}$ from inactivation were observed, the $I_{t o}$ activator NS5806 increased $\mathrm{I}_{\text {to }}$ recovery from inactivation and restored the action potential notch in epicardial cells [263], leading the authors to conclude that some aspects of HF induced electrical remodeling can be reversed by pharmacological activation of $\mathrm{I}_{\text {to }}$.

It is important to note that there are differences in the antiarrhythmic effects of these novel voltage gated potassium channel activators, and some exhibited proarrhythmic effects in certain animal models, therefore more, sufficiently detailed studies are needed to elucidate the cellular cardiac electrophysiological effects of these compounds to assess their effects on other ionic currents.

Another approach to APD prolongation limitation and facilitation of repolarization is the pharmacological activation of sar- colemmal $\mathrm{K}_{\mathrm{ATP}}$ channels to activate steady-state, voltage-independent potassium current. Figure 7 illustrates that activation of sarcolemmal $\mathrm{K}_{\mathrm{ATP}}$ can indeed reduce the dispersion of repolarization between canine ventricular papillary muscle and Purkinje fibers elicited by selective $\mathrm{I}_{\mathrm{Kr}}$ block at slow pacing frequences [170]. Pharmacological activators of $\mathrm{K}_{\mathrm{ATP}}$ have been shown to protect against arrhythmias induced by triggered activity, EADs and DADs [264-266]. The $\mathrm{K}_{\mathrm{ATP}}$ opener nicorandil reduced EADs, shortened monophasic action potential duration and prevented syncope recurrence in patients with congenital LQT and in animal models of LQT [267-269]. Pharmacological activation of $K_{\text {ATP }}$ can reduce calcium overload and improve contractile function [270], and at least in part, this protective mechanism involves resting membrane potential hyperpolarization and reduction in reverse-mode NCX activity [271-272].

However, the activation of sarcolemmal $\mathrm{K}_{\mathrm{ATP}}$ can lead to proarrhythmic side effects, most likely due to excessive APD shortening [273-274]. In a recent optical mapping study the $\mathrm{K}_{\mathrm{ATP}}$ openers diazoxide and pinacidil decreased APD and promoted burst pacing induced arrhythmias in coronary-perfused human atria and ventricles isolated from failing hearts [275]. To reduce myocardial ischemia induced sarcolemmal $\mathrm{K}_{\mathrm{ATP}}$ activation that can result in increased dispersion of repolarization between cardiac tissue regions with different degrees of ischemia, the cardioselective inhibition of $\mathrm{K}_{\text {ATP }}$ channels has been proposed [276]. In addition, the presently available sarcolemmal $\mathrm{K}_{\mathrm{ATP}}$ openers are not selective for cardiac $\mathrm{K}_{\mathrm{ATP}}$ channels and activate vascular smooth muscle $\mathrm{K}_{\mathrm{ATP}}$ channels, reducing total peripheral resistance and decreasing blood pressure [170] that can lead to reflex tachycardia. Therefore, cardiac sarcolemmal $\mathrm{K}_{\mathrm{ATP}}$ activators are needed to properly assess the antiarrhythmic and proarrhythmic effects of cardiac sarcolemmal $\mathrm{K}_{\text {ATP }}$ activation in different pathological settings. The different molecular composition of sarcolemmal $\mathrm{K}_{\mathrm{ATP}}$ channels in different tissue types certainly suggest that this aim can be achieved [277278].

In summary, $\mathrm{K}_{\mathrm{ATP}}$ channel activation can be both antiarrhythmic and proarrhythmic based on actual cardiac pathological settings and degree of ischemia, and the inhibition of sarcolemmal $\mathrm{K}_{\mathrm{ATP}}$ has been suggested as an ischemia selective antiarrhythmic therapeutic modality. The detailed discussion of the role of $\mathrm{K}_{\mathrm{ATP}}$ channels in cardiac arrhythmias is beyond the scope of this paper and the reader is referred to a recent review [170] and an update on this topic in this issue [279].

\section{Kur Blockers}

The atrial specific ultrarapidly activating $\mathrm{I}_{\mathrm{Kur}}$ channel $[164,280]$ has been identified as a very promising target for drug development for the atrial selective pharmacological treatment of AF with little or no ventricular side effects. In line with these expectations, a large number of $\mathrm{I}_{\text {Kur }}$ inhibitor compounds have already been developed and tested in different experimental models in the last 15 years. The comprehensive discussion of these compounds is well beyond the scope of this review and the reader is referred to an excellent re- 

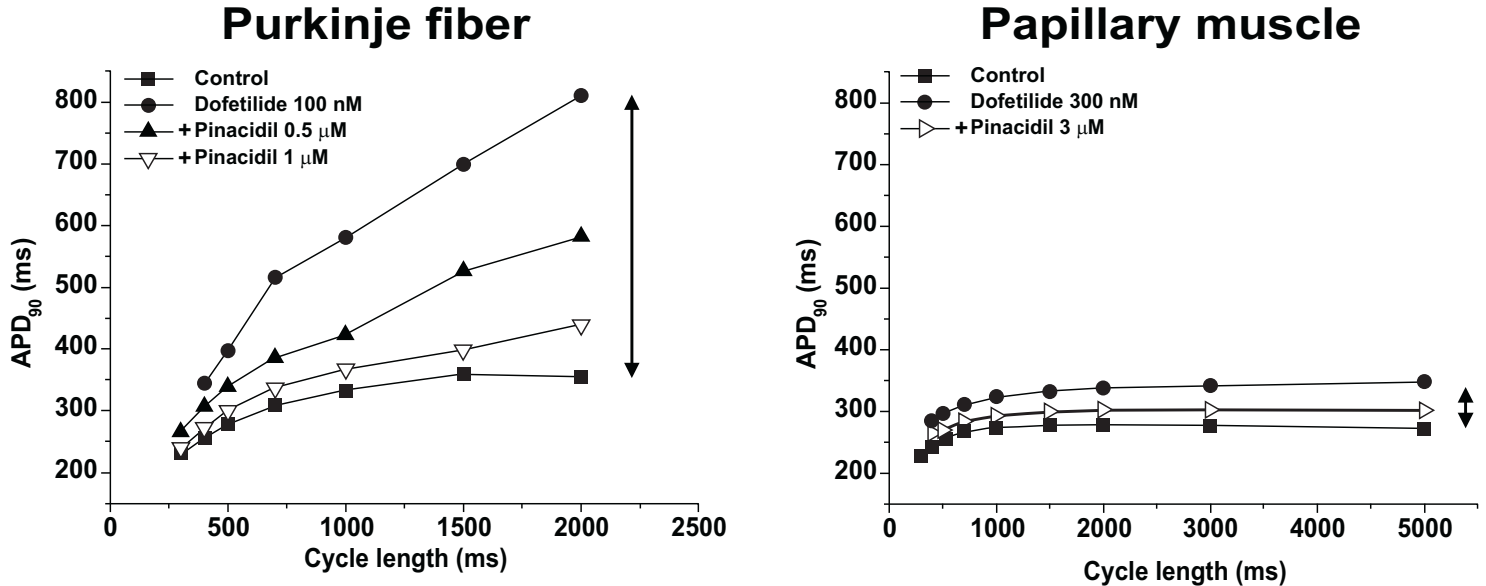

Fig. (7). The cardiac sarcolemmal $\mathrm{K}_{\mathrm{ATP}}$ channel activator pinacidil reduces reverse use-dependent repolarization prolongation and dispersion of repolarization following the administration of the $\mathrm{I}_{\mathrm{Kr}}$ blocker dofetilide in canine Purkinje fibers and papillary muscle. Please note the large difference in cycle length dependent repolarization prolongation in the two preparations. $\mathrm{APD}_{90}$ : action potential duration at $90 \%$ repolarization. Reproduced from [170] with permission.

view on this topic [281]. It is important to note, however, that the selective inhibition of these channels by pure $\mathrm{I}_{\text {Kur }}$ blockers might be somewhat disappointing, since downregulation of $\mathrm{I}_{\mathrm{Kur}}$ in prolonged AF has been reported $[149,151,282]$.

\section{$\mathbf{I}_{\mathrm{K}, \text { ACh }}$ Inhibitors}

GIRK1 and GIRK4 channels conducting acetylcholineactivated potassium current, $\mathrm{I}_{\mathrm{K}, \mathrm{ACh}}$, can be found predominantly in the atria [283], and they mediate the effects of vagal nerve stimulation on the atria via $\mathrm{M}_{2}$ receptors and can induce AF [284]. The activation of these channels shortens atrial APD, atrial effective refractory period and hyperpolarizes the resting membrane potential - all these effects favour the stabilization of AF rotors and promoting re-entry. The constitutive activation of these channels in AF has been shown [159], therefore their inhibition is expected to abolish $\mathrm{AF}$. Indeed, the application of a derivative of the honey bee venom toxin tertiapin, tertiapin- $\mathrm{Q}$ inhibited constitutive $\mathrm{I}_{\mathrm{K}}$, ACh in nanomolar concentrations [285] and was shown to terminate AF in a canine aconitine-induced AF model [286]. Subsequently, the $\mathrm{I}_{\mathrm{K}, \text { ACh }}$ blocking effects and efficacy in experimental AF were reported for a series of novel compounds, including NIP-141, NIP-142, NIP-151 and NTC-801 [287-290]. Some of these compounds inhibit other ionic currents also targeted in the treatment of AF, such as the already discussed $\mathrm{I}_{\mathrm{Kur}}$ [291]. It is not known yet, however, whether these compounds influence ventricular contractility that would interfere with their beneficial effects against AF in the setting of reduced left ventricular function, and few data is available on their effects on chronic AF with atrial remodeling.

\section{NCX Inhibitors}

The $\mathrm{Na}^{+} / \mathrm{Ca}^{2+}$ exchanger is upregulated and its function is enhanced in HF and AF [192-193]. Increased NCX activity can contribute a significant inward current leading to the development of DADs in HF [130]. In a canine heart failure model, inhibition of NCX led to normalization of cellular calcium handling [292], and inhibition of the NCX by SEA-0400 (Fig. 8) prevented EADs and DADs in dog ventricular tissue [293]. However, previously available NCX blockers lacked selectivity, most importantly they also blocked $\mathrm{I}_{\mathrm{Ca}, \mathrm{L}}$ [294], making it very difficult to separate the relative contribution of their NCX blocking and calcium channel blocking effects to the observed results. A very recent publication introduced a novel NCX blocker compound with improved selectivity for the NCX over $\mathrm{I}_{\mathrm{Ca}, \mathrm{L}}, \mathrm{ORM}-10103$ (Fig. 8) [295]. With the identification of this compound it now seems to be feasible to more critically assess the physiological role of the NCX in calcium homeostasis, as well as the effect of NCX inhibition on arrhythmias in the setting of HF.

\section{If Blockers}

An association between elevated resting heart rate and increased risk of mortality has been established in heart failure patients [296]. Therefore, reduction of elevated heart rate in HF patients seems beneficial. Moreover, the increased HCN2 and HCN4 expression in human failing ventricular and atrial cardiomyocytes may contribute to abnormal ectopic activity and trigger arrhythmias in HF [184-186]. In theory, isoform selective $\mathrm{I}_{\mathrm{f}}$ blockers could prevent the triggering activity in $\mathrm{HF}$ occurring through $\mathrm{HCN} 2$ and $\mathrm{HCN} 4$ pathological activation. The most prominent representative $\mathrm{I}_{\mathrm{f}}$ blocker compound, ivabradine is approved for the treatment of angina pectoris in patients who do not tolerate beta adrenergic blockers [297]. In pooled data from the BEAUTIFUL and SHIFT trials, in patients with reduced left ventricular function and elevated heart rate, ivabradine decreased HF associated hospitalization and cardiovascular mortality [298]. Ivabradine is a reasonably selective $\mathrm{I}_{\mathrm{f}}$ current blocker [299], however, additional ion channel blocking effects of ivabradine have been identified that could contribute to its antiarrhythmic activity [300]. Recently, some important steps have been made in the development of new $\mathrm{I}_{\mathrm{f}}$ blockers showing relative isoform selectivity [301], and EC18 was identified as a selective HCN4 blocker that slowed the slope of diastolic depolarization in canine Purkinje fibers [302]. Further studies are needed, however, to determine the effects of isoform selective $\mathrm{I}_{\mathrm{f}}$ blockers on enhanced triggered activity in experimental HF.

\section{Potential Candidates with Combined Mechanism of Action: the Way Forward?}

The development of most of the compounds discussed so far have been following the concept of creating relatively selective ion channel blockers for the treatment of arrhythmias. However, sobering lessons learnt from clinical trials following selective sodium and potassium channel blocker administration in patients with reduced left ventricular function [57-58], and the exceptional efficacy of amiodarone suggests that novel antiarrhythmic drugs with modulatory effects on multiple ion channels may exert beneficial effects in the treatment of atrial and ventricular arrhythmias.

\section{Dronedarone}

Dronedarone is a new multichannel blocker antiarrhythmic drug approved for the treatment of AF. The drug was developed as an amiodarone structural analogue without the iodine moiety in an effort to reduce the serious extracardiac side effects of chronic 
<smiles>CCOc1ccc(Oc2ccc(OCc3cc(F)ccc3F)cc2)c(N)c1</smiles>

SEA-0400<smiles>O=[N+]([O-])c1ccc(Oc2ccc3c(c2)CCC(c2ccccc2)O3)nc1</smiles>

ORM-10103

Fig. (8). Chemical structures of the $\mathrm{Na}^{+} / \mathrm{Ca}^{2+}$ exchanger inhibitors SEA-0400 and ORM-10103.<smiles>Oc1ccc(/C=C/c2cc(O)cc(O)c2)cc1</smiles>

resveratrol<smiles>COc1ccc(CC(=O)NCc2ccccc2-c2ccccc2/C=C/c2ccc(O)cc2)cc1</smiles>

C1

Fig. (9). Chemical structures of resveratrol and Compound 1 (C1).

amiodarone treatment [48]. Dronedarone blocks $\mathrm{I}_{\mathrm{Kr}}, \mathrm{I}_{\mathrm{Ks}}, \mathrm{I}_{\mathrm{K} 1}, \mathrm{I}_{\mathrm{to}}, \mathrm{I}_{\mathrm{Na}}$ and $\mathrm{I}_{\mathrm{Ca}, \mathrm{L}}[303]$. However, dronedarone was found later in the PALLAS clinical trial to increase heart failure events [52], and in the ANDROMEDA trial to increase mortality in patients with severely impaired left ventricular function [50]. Therefore, dronedarone is not recommended to treat arrhythmias in patients with structural heart disease and reduced left ventricular function [33].

\section{Vernakalant}

Vernakalant is a recently introduced antiarrhythmic drug that is relatively atrial specific and blocks several ionic currents, such as $\mathrm{I}_{\mathrm{Kur}}, \mathrm{I}_{\mathrm{to}}, \mathrm{I}_{\mathrm{K}, \mathrm{ACh}}$ and $\mathrm{I}_{\mathrm{Na}}$ [304], and was developed for the treatment of AF. Following intravenous administration, vernakalant effectively converted $\mathrm{AF}$ to sinus rhythm in recent onset and postoperative $\mathrm{AF}$ [305-307]. In a recent clinical trial oral vernakalant was found to be effective for maintaining sinus rhythm following cardioversion of AF [308]. Vernakalant does not exhibit proarrhythmic effects in dogs with chronic atrioventricular block, a model featuring $\mathrm{I}_{\mathrm{Ks}}$ downregulation, bradycardia and increased susceptibility to arrhythmias [309]. No proarrhythmic adverse effects were found in a rabbit proarrhythmia model [310] or in a recent clinical trial [308]. In $\mathrm{AF}$ associated with $\mathrm{HF}$, vernakalant appears to be less effective for cardioversion and increased incidence of serious hypotensive episodes and ventricular arrhythmias were detected in patients with left ventricular dysfunction [311]. Vernakalant is currently approved in Europe for the conversion of recent onset AF.

The complex etiology of AF and the multiple mechanisms responsible for the development and maintenance of AF led to the suggestion that novel compounds targeting several pathways involved in AF may exhibit improved efficacy [312-313]. In this regard, resveratrol, an intensively investigated red grape polyphenol that possesses cardioprotective properties [216] could serve as a potential parent compound for the development of future drugs to treat both $\mathrm{AF}$ and heart failure associated ventricular arrhythmias. Resveratrol has been shown to inhibit NFAT activation [314], a pathway implicated in AF [315] and pathological cardiac hypertrophy [316]. Resveratrol also inhibited hypertrophic remodeling [317], as well as late $\mathrm{I}_{\mathrm{Na}}$ with preference over peak $\mathrm{I}_{\mathrm{Na}}$ [218]. Indeed, in a very recent study Compound 1 (C1; Fig. 9), a resveratrol derivative was shown to possess multi-channel blocking properties and exhibited efficacy against $\mathrm{AF}$ in a chronic atrial tachypacing induced atrial fibrillation dog model [233]. This novel compound inhibited peak and late $\mathrm{I}_{\mathrm{Kur}}\left(\mathrm{IC}_{50}: 0.36\right.$ and $0.11 \mu \mathrm{mol} / 1$, respectively), $\mathrm{I}_{\mathrm{K}, \mathrm{ACh}}\left(\mathrm{IC}_{50}: 1.9 \mu \mathrm{mol} / \mathrm{l}\right)$, peak $\mathrm{I}_{\mathrm{Na}}$ and $\mathrm{I}_{\mathrm{Na}}$, late $\left(\mathrm{IC}_{50}: 3.0\right.$ and $1 \mu \mathrm{mol} / 1$, respectively), demonstrated NFAT inhibitory and antioxidant properties that were similar to those of resveratrol. Importantly, C1 showed only weak hERG channel inhibition and did not prolong the QT interval in conscious dogs, suggesting that the compound did not significantly influence ventricular repolarization and was unlikely to provoke ventricular arrhythmias. Based on these effects, it was concluded that $\mathrm{C} 1$ as a multifunctional small molecule targeting several key pathways involved in the development and maintenance of AF.

\section{SUMMARY}

Heart failure and atrial fibrillation are the "two new epidemics of cardiovascular disease" [18]. Both HF and AF are associated with significant morbidity and mortality and their prevalence icreases with age. The two conditions are often diagnosed together and the development of the other condition further deteriorates the prognosis. Almost half of HF patients die due to ventricular fibrillation, and AF leads to increased mortality due to increased risk for stroke and heart failure. Both chronic HF and AF lead to structural and electrical remodeling of the heart that can significantly alter targets for pharmacological antiarrhythmic treatment. Current pharmacological approaches for the management of HF associated ventricular arrhythmias and AF lack efficacy and often lead to serious cardiovascular and/or extracardiac adverse events. For the treatment of ventricular arrhythmias in HF, novel approaches may include improving electrical remodeling impaired repolarization capacity via the activation of selected potassium currents and/or inhibition of abnormal depolarizing currents, normalization of impaired conduction and improving dysfunctional intracellular calcium homeostasis. Future pharmacological treatment of AF may focus on atrial selective modulation of ionic currents to avoid ventricular side effects and targeting other mechanisms involved in AF generation and maintenance with multifunctional compounds, with particular attention paid to avoid adverse effects in patients with left ventricular dysfunction. However, the upstream treatment of both conditions aiming at the reduction of disease induced remodeling is also emphasized. Due to the heterogenous mechanisms involved in ventricular and atrial arrhythmia development, it is expected that 
compounds with multiple mechanisms of action may show improved efficacy in the treatment of arrhythmias in heart failure.

\begin{tabular}{|c|c|c|}
\hline \multicolumn{3}{|c|}{ ABBREVIATIONS } \\
\hline $\mathrm{AF}$ & $=$ & Atrial fibrillation \\
\hline APD & $=$ & Action potential duration \\
\hline $\mathrm{Cx} 43$ & $=$ & Connexin 43 \\
\hline $\mathrm{HF}$ & $=$ & Heart failure \\
\hline $\mathrm{I}_{\mathrm{K} 1}$ & $=$ & Inwardly rectifying potassium current \\
\hline $\mathrm{I}_{\mathrm{Kr}}$ & $=$ & $\begin{array}{l}\text { Rapid component of the delayed rectifier potas- } \\
\text { sium current }\end{array}$ \\
\hline $\mathrm{I}_{\mathrm{Ks}}$ & $=$ & $\begin{array}{l}\text { Slow component of the delayed rectifier potas- } \\
\text { sium current }\end{array}$ \\
\hline $\mathrm{I}_{\text {Kur }}$ & $=$ & Ultra-rapidly activating potassium current \\
\hline $\mathrm{I}_{\text {to }}$ & $=$ & Transient outward potassium current \\
\hline $\mathrm{I}_{\mathrm{Na}, \mathrm{L}}$ & $=$ & Late or persistent sodium current \\
\hline $\mathrm{I}_{\mathrm{KATP}}$ & $=$ & $\begin{array}{l}\text { Adenosine-triphosphate sensitive potassium cur- } \\
\text { rent }\end{array}$ \\
\hline $\mathrm{I}_{\mathrm{K}, \mathrm{ACh}}$ & $=$ & Acetylcholine-regulated potassium current \\
\hline NCX & $=$ & $\mathrm{Na}^{+} / \mathrm{Ca}^{2+}$ exchanger \\
\hline SCD & $=$ & Sudden cardiac death \\
\hline $\mathrm{TdP}$ & $=$ & Torsades de Pointes \\
\hline VF & $=$ & Ventricular fibrillation \\
\hline $\mathrm{V}_{\max }$ & $=$ & Maximum rate of depolarization \\
\hline
\end{tabular}

\section{CONFLICT OF INTEREST}

The authors confirm that this article content has no conflict of interest.

\section{ACKNOWLEDGEMENTS}

Funding is acknowledged from grants by the Hungarian Scientific Research Fund (OTKA K109610, NN110896, NK104331); by the HU-RO Cross-Border Cooperation Programmes (HUROTWIN, HURO/1101/086/2.2.1) and the Romanian National Research Council Grant - Project IDEAS - Programme "Exploratory Research Projects" PN-II-ID-PCE-2012-4-0512. This research was supported in the framework of TÁMOP 4.2.4. A/2-11-1-2012-0001 „National Excellence Program - Elaborating and operating an inland student and researcher personal support system" key project. The project was subsidized by the European Union and co-financed by the European Social Fund to I.B. Funding is acknowledged by operating grants from the Canadian Institutes of Health Research, Alberta Innovates - Health Solutions/Pfizer Translational grant and the Alberta Heart Failure Etiology and Analysis Research Team (Alberta HEART), funded by Alberta Innovates - Health Solutions Interdisciplinary Team Grant \#AHFMR ITG 200801018. P.E.L. is the holder of the Charles A. Allard Chair in Diabetes Research.

\section{REFERENCES}

[1] Heo S, Doering LV, Widener J, et al. Predictors and effect of physical symptom status on health-related quality of life in patients with heart failure. Am J Crit Care 2008; 17: 124-32.

[2] Go AS, Mozaffarian D, Roger VL, et al. Heart disease and stroke statistics-2013 update: a report from the American Heart Association. Circulation 2013; 127: e6-245.

[3] Curtis LH, Whellan DJ, Hammill BG, et al. Incidence and prevalence of heart failure in elderly persons, 1994-2003. Arch Intern Med 2008; 168: 418-24.

[4] Roger VL, Weston SA, Redfield MM, et al. Trends in heart failure incidence and survival in a community-based population. JAMA 2004; 292: 344-50.

[5] Francis GS. Development of arrhythmias in the patient with congestive heart failure: pathophysiology, prevalence and prognosis. Am J Cardiol 1986; 57: 3B-7B.
[6] Kjekshus J. Arrhythmias and mortality in congestive heart failure. Am J Cardiol 1990; 65: 421-81.

[7] Sanders P, Kistler PM, Morton JB, et al. Remodeling of sinus node function in patients with congestive heart failure: reduction in sinus node reserve. Circulation 2004; 110: 897-903.

[8] Alboni P, Brignole M, Menozzi C, et al. Is sinus bradycardia a factor facilitating overt heart failure? Eur Heart J 1999; 20: 252-55.

[9] Burkhardt JD, Wilkoff BL. Interventional electrophysiology and cardiac resynchronization therapy: delivering electrical therapies for heart failure. Circulation 2007; 115: 2208-20.

[10] Kannel WB, Abbott RD, Savage DD, et al. Epidemiologic features of chronic atrial fibrillation: the Framingham study. N Engl J Med 1982; 306: 1018-22.

[11] Wolf PA, Abbott RD, Kannel WB. Atrial fibrillation as an independent risk factor for stroke: the Framingham Study. Stroke 1991; 22: 983-88.

[12] McManus DD, Rienstra M, Benjamin EJ. An update on the prognosis of patients with atrial fibrillation. Circulation 2012;126: e143-46.

[13] Benjamin EJ, Levy D, Vaziri SM, et al. Independent risk factors for atrial fibrillation in a population-based cohort: the Framingham Heart Study. JAMA 1994; 271: 840-44.

[14] Naccarelli GV, Varker H, Lin J, et al. Increasing prevalence of atrial fibrillation and flutter in the United States. Am J Cardiol 2009; 104: 1534-39.

[15] Wang TJ, Larson MG, Levy D, et al. Temporal relations of atrial fibrillation and congestive heart failure and their joint influence on mortality: the Framingham Heart Study. Circulation 2003; 107: 2920-25.

[16] Dries DL, Exner DV, Gersh BJ, et al. Atrial fibrillation is associated with an increased risk for mortality and heart failure progression in patients with asymptomatic and symptomatic left ventricular systolic dysfunction: a retrospective analysis of the SOLVD trials. J Am Coll Cardiol 1998; 32: 695-703.

[17] Maisel WH, Stevenson LW. Atrial fibrillation in heart failure: epidemiology, pathophysiology, and rationale for therapy. Am J Cardiol 2003; 91: 2D-8D

[18] Braunwald E. Shattuck lecture: cardiovascular medicine at the turn of the millennium. Triumphs, concerns, and opportunities. N Engl J Med 1997; 337: 1360-69.

[19] Benjamin EJ, Wolf PA, D'Agostino RB, et al. Impact of atrial fibrillation on the risk of death: the Framingham Heart Study. Circulation 1998; 98: 946-52.

[20] Nattel S, Maguy A, Le Bouter S, et al. Arrhythmogenic ionchannel remodeling in the heart: heart failure, myocardial infarction, and atrial fibrillation. Physiol Rev 2007; 87: 425-56.

[21] Yu WC, Chen SA, Chiang CE, et al. Effect of high intensity drive train stimulation on dispersion of atrial refractoriness: role of autonomic nervous system. J Am Coll Cardiol 1997; 29: 1000-6.

[22] Nerheim P, Birger-Botkin S, Piracha L, et al. Heart failure and sudden death in patients with tachycardia-induced cardiomyopathy and recurrent tachycardia. Circulation 2004; 110: 247-52.

[23] Pozzoli M, Cioffi G, Traversi E, et al. Predictors of primary atrial fibrillation and concomitant clinical and hemodynamic changes in patients with chronic heart failure: a prospective study in 344 patients with baseline sinus rhythm. J Am Coll Cardiol 1998; 32: 197204.

[24] Crijns HJ, van den Berg MP, van Gelder IC, et al. Management of atrial fibrillation in the setting of heart failure. Eur Heart J 1997; 18: C45-9.

[25] Li D, Fareh S, Leung TK, et al. Promotion of atrial fibrillation by heart failure in dogs: atrial remodeling of a different sort. Circulation $1999 ; 100: 87-95$.

[26] Roy D, Talajic M, Dorian P, et al. Amiodarone to prevent recurrence of atrial fibrillation. N Engl J Med 2000; 342: 913-20.

[27] AFFIRM First Antiarrhythmic Drug Substudy Investigators. Maintenance of sinus rhythm in patients with atrial fibrillation. J Am Coll Cardiol 2003; 42: 20-9.

[28] Singh BN, Singh SN, Reda DJ, et al. Amiodarone versus sotalol for atrial fibrillation. N Engl J Med 2005; 352: 1861-72.

[29] Bajpai A, Savelieva I, Camm AJ. Treatment of atrial fibrillation. $\mathrm{Br}$ Med Bull 2008; 88: 75-94.

[30] Roy D, Talajic M, Nattel S, et al. on behalf of the Atrial Fibrillation and Congestive Heart Failure (AF-CHF) Investigators. Rhythm Control Versus Rate Control for Atrial Fibrillation and Heart Failure. N Engl J Med 2008; 358: 2667-77. 
[31] Farshi R, Kistner D, Sarma JS, et al. Ventricular rate control in chronic atrial fibrillation during daily activity and programmed exercise: a crossover open-label study of five drug regimens. J Am Coll Cardiol 1999; 33: 304-10.

[32] Khand AU, Rankin AC, Martin W, et al. Carvedilol alone or in combination with digoxin for the management of atrial fibrillation in patients with heart failure? J Am Coll Cardiol 2003; 42: 194451 .

[33] Yancy CW, Jessup M, Bozkurt B, et al. 2013 ACCF/AHA guideline for the management of heart failure: a report of the American College of Cardiology Foundation/American Heart Association Task Force on Practice Guidelines. J Am Coll Cardiol 2013; 62: e147-239.

[34] Moss AJ, Hall WJ, Cannom DS, et al. Cardiac-resynchronization therapy for the prevention of heart-failure events. N Engl J Med 2009; 361: 1329-38.

[35] Tang AS, Wells GA, Talajic M, et al. Cardiac-resynchronization therapy for mild-to-moderate heart failure. N Engl J Med 2010; 363: 2385-95

[36] Fung JW, Sanderson JE, Yip GW, et al. Impact of atrial fibrillation in heart failure with normal ejection fraction: a clinical and echocardiographic study. J Card Fail 2007; 13: 649-55.

[37] Flaker GC, Blackshear JL, McBride R, et al. Antiarrhythmic drug therapy and cardiac mortality in atrial fibrillation. J Am Coll Cardiol 1992; 20: 527-32

[38] Echt DS, Liebson PR, Mitchell LB, et al. Mortality and morbidity in patients receiving encainide, flecainide, or placebo. The Cardiac Arrhythmia Suppression Trial. N Engl J Med 1991; 324: 781-8.

[39] Hallstrom A, Pratt CM, Greene HL, et al. Relations between heart failure, ejection fraction, arrhythmia suppression and mortality: Analysis of the Cardiac Arrhythmia Suppression Trial. J Am Coll Cardiol 1995; 25: 1250-7.

[40] Coplen SE, Antman EM, Berlin JA, et al. Efficacy and safety of quinidine therapy for maintenance of sinus rhythm after cardioversion. A meta-analysis of randomized trials. Circulation 1990; 82: 1106-16.

[41] Fuster V, Rydén LE, Cannom DS, et al. 2011 ACCF/AHA/HRS focused updates incorporated into the ACC/AHA/ESC 2006 guidelines for the management of patients with atrial fibrillation: a report of the American College of Cardiology Foundation/American Heart Association Task Force on Practice Guidelines. J Am Coll Cardiol 2011; 57: e101-98.

[42] Torp-Pedersen C, Moller M, Bloch-Thomsen PE, et al. Dofetilide in patients with congestive heart failure and left ventricular dysfunction: Danish Investigations of Arrhythmia and Mortality on Dofetilide Study Group. N Engl J Med 1999; 341: 857-65.

[43] Brendorp B, Elming H, Jun L, et al. QTc interval as a guide to select those patients with congestive heart failure and reduced left ventricular systolic function who will benefit from antiarrhythmic treatment with dofetilide. Circulation 2001; 103: 1422-27.

[44] Lehmann M, Hardy S, Archibald D, et al. Sex difference in risk of torsade de pointes with d, 1-sotalol. Circulation 1996; 94: 2534-41.

[45] Hohnloser SH, Singh BN. Proarrhythmia with class III antiarrhythmic drugs: Definition, electrophysiologic mechanisms, incidence, predisposing factors, and clinical implications. J Cardiovasc Electrophysiol 1995; 6: 920-36.

[46] Hohnloser SH, Klingenheben T, Singh BN. Amiodarone-associated proarrhythmic effects. A review with special reference to torsade de pointes tachycardia. Ann Intern Med 1994; 121: 529-35.

[47] Middlekauff HR, Stevenson WG, Saxon LA, et al. Amiodarone and torsades de pointes in patients with advanced heart failure. Am J Cardiol 1995; 76: 499-502.

[48] Yalta K, Turgut OO, Yilmaz MB, et al. Dronedarone: a promising alternative for the management of atrial fibrillation. Cardiovasc Drugs Ther 2009; 23: 385-93.

[49] Le Heuzey JY, De Ferrari GM, Radzik D, et al. A short-term, randomized, double-blind, parallel-group study to evaluate the efficacy and safety of dronedarone versus amiodarone in patients with persistent atrial fibrillation: the DIONYSOS study. J Cardiovasc Electrophysiol 2010; 21: 597-605.

[50] Kober L, Torp-Pedersen C, McMurray JJ, et al. Increased mortality after dronedarone therapy for severe heart failure. N Engl J Med 2008; 358: 2678-87.

[51] Connolly SJ, Camm AJ, Halperin JL, et al. Dronedarone in highrisk permanent atrial fibrillation. N Engl J Med 2011; 365: 226876.
[52]

Salam AM. Dronedarone in atrial fibrillation: the aftermath of the PALLAS trial. Expert Rev Cardiovasc Ther 2012; 10: 1345-9.

[53] Anderson JL, Halperin JL, Albert NM, et al. Management of patients with atrial fibrillation (compilation of 2006 ACCF/AHA/ESC and $2011 \mathrm{ACCF} / \mathrm{AHA} / \mathrm{HRS}$ guideline recommendations): a report of the American College of Cardiology Foundation/American Heart Association Task Force on Practice Guidelines. J Am Coll Cardiol 2013; 61: 1935- 44.

[54] Hart RG, Pearce LA, McBride R, et al. Factors associated with ischemic stroke during aspirin therapy in atrial fibrillation: analysis of 2012 participants in the SPAF I-III clinical trials. The Stroke Prevention in Atrial Fibrillation (SPAF) Investigators. Stroke 1999; 30: 1223-9.

[55] Ahmad Y, Lip GY. Stroke prevention in atrial fibrillation: concepts and controversies. Curr Cardiol Rev 2012; 8: 290-301.

[56] Banerjee A, Lane DA, Torp-Pedersen C, et al. Net clinical benefit of new oral anticoagulants (dabigatran, rivaroxaban, apixaban) versus no treatment in a 'real world' atrial fibrillation population: a modelling analysis based on a nationwide cohort study. Thromb Haemost 2012; 107: 584-9.

[57] The Cardiac Arrhythmia Suppression Trial (CAST) Investigators. Preliminary report: effect of encainide and flecainide on mortality in a randomized trial of arrhythmia suppression after after myocardial infarction. N Engl J Med 1989; 321: 406-12.

[58] Waldo AL, Camm AJ, deRuyter H, et al. Effect of D-sotalol on mortality in patients with left ventricular dysfunction after recent and remote myocardial infarction. The SWORD investigators. Survival with oral D-sotalol. Lancet 1996; 348: 7-12.

[59] Doval HC, Nul DR, Grancelli HO, et al. Randomised trial of lowdose amiodarone in severe congestive heart failure: Grupo de Estudio de la Sobrevida en la Insuficiencia Cardiaca en Argentina (GESICA). Lancet 1994; 344: 493-8.

[60] Singh SN, Fletcher RD, Fisher SG, et al. Amiodarone in patients with congestive heart failure and asymptomatic ventricular arrhythmia: Survival Trial of Antiarrhythmic Therapy in Congestive Heart Failure. N Engl J Med 1995; 333: 77-82.

[61] Kober L, Bloch Thomsen PE, Moller M, et al. Effect of dofetilide in patients with recent myocardial infarction and left-ventricular dysfunction: a randomised trial. Lancet 2000; 356: 2052-8.

[62] Friedman L, Alexander E. Update of the clinical impact and issues surrounding Dofetilide (Tikosyn) therapy. AACN Adv Crit Care. 2006; 17: 102-8.

[63] Brumberg G, Gera N, Pray C, et al. Frequency of toxicity with chemical conversion of atrial fibrillation with dofetilide. Am J Cardiol. 2013; 112 : 505-8.

[64] Chun SH, Sager PT, Stevenson WG, et al. Long-term efficacy of Amiodarone for the maintenance of normal sinus rhythm in patients with refractory atrial fibrillation or flutter. Am J Cardiol 1995; 76: 47-50.

[65] Crijns HJ, Van Gelder IC, Van Gilst WH, et al. Serial antiarrhythmic drug treatment to maintain sinus rhythm after electrical cardioversion for chronic atrial fibrillation or atrial flutter. Am J Cardiol 1991; 68: 335-41

[66] Wood MA, Brown-Mahoney C, Kay GN, et al. Clinical outcome after ablation and pacing therapy for atrial fibrillation. A metaanalysis. Circulation 2000; 101: 1138-44.

[67] Wilber DJ, Pappone C, Neuzil P, et al. ThermoCool AF Trial Investigators. Comparison of antiarrhythmic drug therapy and radiofrequency catheter ablation in patients with paroxysmal atrial fibrillation: a randomized controlled trial. JAMA 2010; 303: 333-40.

[68] Haissaguerre M, Jais P, Shah DC, et al. Spontaneous initiation of atrial fibrillation by ectopic beats originating from the pulmonary veins. N Engl J Med 1998; 339: 659-66.

[69] Pappone C, Rosanio S, Oreto G, et al. Circumferential radiofrequency ablation of pulmonary vein ostia. A new anatomic approach for curing atrial fibrillation. Circulation 2000; 102: 2619-28.

[70] Gentlesk PJ, Sauer WH, Gerstenfeld EP, et al. Reversal of left ventricular dysfunction following ablation of atrial fibrillation. $\mathbf{J}$ Cardiovasc Electrophysiol 2007; 18: 9-14.

[71] Khan MN, Jaïs P, Cummings J, et al. PABA-CHF Investigators. Pulmonary-vein isolation for atrial fibrillation in patients with heart failure. N Engl J Med 2008; 359: 1778-85.

[72] Wilton SB, Fundytus A, Ghali WA, et al. Meta-analysis of the effectiveness and safety of catheter ablation of atrial fibrillation in patients with versus without left ventricular systolic dysfunction. Am J Cardiol 2010; 106: 1284-91. 
[73] Marrouche NF, Brachmann J, CASTLE-AF Steering Committee. Catheter ablation versus standard conventional treatment in patients with left ventricular dysfunction and atrial fibrillation (CASTLEAF) - study design. Pacing Clin Electrophysiol. 2009; 32: 987-94.

[74] Cleland JG, Coletta AP, Buga L, et al. Clinical trials update from the American College of Cardiology meeting 2010: DOSE, ASPIRE, CONNECT, STICH, STOP-AF, CABANA, RACE II, EVEREST II, ACCORD, and NAVIGATOR. Eur J Heart Fail 2010; 12: 623-9.

[75] Calkins H, Kuck KH, Cappato R, et al. 2012 HRS/EHRA/ECAS Expert Consensus Statement on Catheter and Surgical Ablation of Atrial Fibrillation: Recommendations for Patient Selection, Procedural Techniques, Patient Management and Follow-up, Definitions, Endpoints, and Research Trial Design. Europace 2012; 14: 528606.

[76] Gottlieb SS, Kukin ML, Medina N, et al. Comparative hemodynamic effects of procainamide, tocainide, and encainide in severe chronic heart failure. Circulation 1990; 81: 860-64

[77] Moss AJ, Zareba W, Hall WJ, et al. Prophylactic implantation of a defibrillator in patients with myocardial infarction and reduced ejection fraction. N Engl J Med 2002; 346: 877-83.

[78] Hohnloser SH, Kuck KH, Dorian P, et al. Prophylactic use of an implantable cardioverter-defibrillator after acute myocardial infarction. N Engl J Med 2004; 351: 2481-8.

[79] Bardy GH, Lee KL, Mark DB, et al. Sudden Cardiac Death in Heart Failure Trial (SCD-HeFT) Investigators. Amiodarone or an implantable cardioverter-defibrillator for congestive heart failure. N Engl J Med 2005; 352: 225-37.

[80] Strickberger SA, Hummel JD, Bartlett TG, et al. AMIOVIRT Investigators. Amiodarone versus implantable cardioverterdefibrillator: randomized trial in patients with nonischemic dilated cardiomyopathy and asymptomatic nonsustained ventricular tachycardia--AMIOVIRT. J Am Coll Cardiol 2003; 41: 1707-12.

[81] Kadish A, Dyer A, Daubert JP, et al. Defibrillators in NonIschemic Cardiomyopathy Treatment Evaluation (DEFINITE) Investigators. Prophylactic defibrillator implantation in patients with nonischemic dilated cardiomyopathy. N Engl J Med 2004; 350: 2151-8.

[82] Earley A, Persson R, Garlitski AC, et al. Effectiveness of implantable cardioverter defibrillators for primary prevention of sudden cardiac death in subgroups a systematic review. Ann Intern Med 2014; 160: 111-21.

[83] McAlister FA, Ezekowitz JA, Wiebe N, et al. Systematic review: cardiac resynchronization in patients with symptomatic heart failure. Ann Intern Med 2004; 141: 381-90.

[84] Burkhardt JD, Wilkoff BL. Interventional electrophysiology and cardiac resynchronization therapy. Circulation 2007; 115: 2208-20. Shamim W, Francis DP, Yousufuddin M, et al. Intraventricular conduction delay: a prognostic marker in chronic heart failure. Int J Cardiol 1999; 70: 171-8.

[86] Kirk JA, Kass DA. Electromechanical dyssynchrony and resynchronization of the failing heart. Circ Res 2013; 113: 765-76.

[87] Prinzen FW, Vernooy K, Auricchio A. Cardiac resynchronization therapy: state-of-the-art of current applications, guidelines, ongoing trials, and areas of controversy. Circulation 2013; 128: 2407-18.

[88] Epstein AE, DiMarco JP, Ellenbogen KA, et al. American College of Cardiology Foundation; American Heart Association Task Force on Practice Guidelines; Heart Rhythm Society. 2012 ACCF/ AHA/HRS focused update incorporated into the ACCF/AHA/HRS 2008 guidelines for device-based therapy of cardiac rhythm abnormalities: a report of the American College of Cardiology Foundation/American Heart Association Task Force on Practice Guidelines and the Heart Rhythm Society. Circulation 2013; 127: e283352.

[89] Cleland JG, Daubert JC, Erdmann E, et al. Cardiac Resynchronization-Heart Failure (CARE-HF) Study Investigators. The effect of cardiac resynchronization on morbidity and mortality in heart failure. N Engl J Med 2005; 352: 1539-49.

[90] Cleland JG, Freemantle N, Erdmann E, et al. Long-term mortality with cardiac resynchronization therapy in the Cardiac Resynchronization-Heart Failure (CARE-HF) trial. Eur J Heart Fail 2012; 14: 628-34.

[91] Santangeli P, Di Biase L, Pelargonio G, et al. Cardiac resynchronization therapy in patients with mild heart failure: a systematic review and meta-analysis. J Interv Card Electrophysiol 2011; 32: 125-35.
[92] Adabag S, Roukoz H, Anand IS, et al. Cardiac resynchronization therapy in patients with minimal heart failure: a systematic review and meta-analysis. J Am Coll Cardiol 2011; 58: 935-41.

[93] Hoppe UC, Casares JM, Eiskjaer H, et al. Effect of cardiac resynchronization on the incidence of atrial fibrillation in patients with severe heart failure. Circulation 2006; 114: 18-25

[94] Hauck M, Bauer A, Voss F, et al. Effect of cardiac resynchronization therapy on conversion of persistent atrial fibrillation to sinus rhythm. Clin Res Cardiol 2009; 98: 189-94.

[95] Gasparini M, Steinberg JS, Arshad A, et al. Resumption of sinus rhythm in patients with heart failure and permanent atrial fibrillation undergoing cardiac resynchronization therapy: a longitudinal observational study. Eur Heart J 2010; 31: 976-83.

[96] Hess PL, Jackson KP, Hasselblad V, et al. Is cardiac resynchronization therapy an antiarrhythmic therapy for atrial fibrillation? A systematic review and meta-analysis. Curr Cardiol Rep 2013; 15: 330 .

[97] Kantharia BK, Patel JA, Nagra BS, et al. Electrical storm of monomorphic ventricular tachycardia after a cardiac-resynchronizationtherapy-defibrillator upgrade. Europace 2006; 8: 625- 28.

[98] Bortone A, Macia JC, Leclercq F, et al. Monomorphic ventricular tachycardia induced by cardiac resynchronization therapy in patient with severe nonischemic dilated cardiomyopathy. Pacing Clin Electrophysiol 2006; 29: 327-30.

[99] Voigt A, Barrington W, Ngwu O, et al. Biventricular pacing reduces ventricular arrhythmic burden and defibrillator therapies in patients with heart failure. Clin Cardiol 2006; 29: 74-7.

[100] McSwain RL, Schwartz RA, DeLurgio DB, et al. The impact of cardiac resynchronization therapy on ventricular tachycardia/fibrillation: an analysis from the combined Contak-CD and InSync-ICD studies. J Cardiovasc Electrophysiol 2005; 16: 1168-71.

[101] Bristow MR, Saxon LA, Boehmer J, et al. Comparison of Medical Therapy, Pacing, and Defibrillation in Heart Failure (COMPANION) Investigators. Cardiac-resynchronization therapy with or without an implantable defibrillator in advanced chronic heart failure. N Engl J Med 2004; 350: 2140-50.

[102] Ermis C, Seutter R, Zhu AX, et al. Impact of upgrade to cardiac resynchronization therapy on ventricular arrhythmia frequency in patients with implantable cardioverter-defibrillators. J Am Coll Cardiol 2005; 46: $2258-63$.

[103] Kirkfeldt RE, Johansen JB, Nohr EA, et al. Complications after cardiac implantable electronic device implantations: an analysis of a complete, nationwide cohort in Denmark. Eur Heart J 2013 Dec 17. epub.

[104] Nery PB, Fernandes R, Nair GM, et al. Device-related infection among patients with pacemakers and implantable defibrillators: incidence, risk factors, and consequences. J Cardiovasc Electrophysiol. 2010; 21: 786-90.

[105] Wilton SB, Leung AA, Ghali WA, et al. Outcomes of cardiac resynchronization therapy in patients with versus those without atrial fibrillation: a systematic review and meta-analysis. Heart Rhythm 2011; 8: 1088-94

[106] Nair GM, Nery PB, Redpath CJ, et al. Ventricular arrhythmias in patients with heart failure secondary to reduced ejection fraction: a current perspective. Curr Opin Cardiol 2014; 29: 152-9.

[107] Moss AJ, Schuger C, Beck CA, et al. Reduction in inappropriate therapy and mortality through ICD programming. N Engl J Med 2012; 367: 2275-83

[108] Ferreira-Gonzalez I, Dos-Subira L, Guyatt GH. Adjunctive antiarrhythmic drug therapy in patients with implantable cardioverter defibrillators: a systematic review. Eur Heart J 2007; 28: 469-77.

[109] Burstein B, Nattel S. Atrial structural remodelling as an antiarrhythmic target. J Cardiovasc Pharmacol 2008; 52: 4-10.

[110] Jost N, Kohajda Z, Kristóf A, et al. Atrial remodeling and novel pharmacological strategies for antiarrhythmic therapy in atrial fibrillation. Curr Med Chem 2011; 18: 3675-94.

[111] Schram G, Pourrier M, Melnyk P, et al. Differential distribution of cardiac ion channel expression as a basis for regional specialization in electrical function. Circ Res 2002; 90: 939-50.

[112] Nerbonne JM, Kass RS. Molecular physiology of cardiac repolarization. Physiol Rev 2005; 85: 1205-53.

[113] Vermeulen JT, McGuire MA, Opthof T, et al. Triggered activity and automaticity in ventricular trabeculae of failing human and rabbit hearts. Cardiovasc Res 1994; 24: 1547-54. 
[114] Nuss HB, Kaab S, Kass DA, et al. Cellular basis of ventricular arrhythmias and abnormal automaticity in heart failure. Am J Physiol 1999; 277: H80-91.

[115] Janse MJ. Electrophysiological changes in heart failure and their relationship to arrhythmogenesis. Cardiovasc Res 2004; 61: 20817.

[116] Michael G, Xiao L, Qi XY, Dobrev D, Nattel S. Remodelling of cardiac repolarization: how homeostatic responses can lead to arrhythmogenesis. Cardiovasc Res 2009; 81: 491-9.

[117] Li GR, Lau CP, Leung TK, et al. Ionic current abnormalities associated with prolonged action potentials in cardiomyocytes from diseased human right ventricles. Heart Rhythm 2004; 1: 460 - 8.

[118] Zeng J, Rudy Y. Early afterdepolarizations in cardiac myocytes: mechanism and rate dependence. Biophys J 1995; 68: 949-64.

[119] El-Sherif N, Turitto G. The long QT syndrome and torsade de pointes. Pacing Clin Electrophysiol 1999; 22: 91-110.

[120] Valdivia CR, Chu WW, Pu J, et al. Increased late sodium current in myocytes from a canine heart failure model and from failing human heart. J Mol Cell Cardiol 2005; 38: 475-83.

[121] Shryock JC, Song Y, Rajamani S, et al. The arrhythmogenic consequences of increasing late $\mathrm{I}_{\mathrm{Na}}$ in the cardiomyocyte. Cardiovasc Res 2013; 99: 600-11.

[122] Horvath B, Banyasz T, Jian Z, et al. Dynamics of the late $\mathrm{Na}^{+}$ current during cardiac action potential and its contribution to afterdepolarizations. J Mol Cell Cardiol 2013; 64: 59-68.

[123] Kaab S, Nuss HB, Chiamvimonvat N, et al. Ionic mechanism of action potential prolongation in ventricular myocytes from dogs with pacing-induced heart failure. Circ Res 1996; 78: 262-73.

[124] Tomaselli GF, Marban E. Electrophysiological remodelling in hypertrophy and heart failure. Cardiovasc Res 1999; 42: 270-83.

[125] Li GR, Lau CP, Ducharme A, et al. Transmural action potential and ionic current remodelling in ventricles of failing canine hearts. Am J Physiol Heart Circ Physiol 2002; 283: H1031-41.

[126] Ouadid H, Albat B, Nargeot J. Calcium currents in diseased human cardiac cells. J Cardiovasc Pharmacol 1995; 25: 282-91.

[127] Bers DM. Calcium cycling and signaling in cardiac myocytes. Annu Rev Physiol 2008; 70: 23-49.

[128] Terracciano CM, Philipson KD, MacLeod KT. Overexpression of the $\mathrm{Na}^{+} / \mathrm{Ca}^{2+}$ exchanger and inhibition of the sarcoplasmic reticulum $\mathrm{Ca}^{2+}$-ATPase in ventricular myocytes from transgenic mice. Cardiovasc Res 2001; 49: 38-47.

[129] Blaustein MP, Lederer WJ. Sodium/calcium exchange: its physiological implications. Physiol Rev 1999; 79, 763-854.

[130] Bers DM, Despa S, Bossuyt J. Regulation of $\mathrm{Ca}^{2+}$ and $\mathrm{Na}^{+}$in normal and failing cardiac myocytes. Ann N Y Acad Sci 2006; 1080: 165-77.

[131] Beuckelmann DJ, Nabauer M, Erdmann E. Alterations of K+ currents in isolated human ventricular myocytes from patients with terminal heart failure. Circ Res 1993; 73: 379-85.

[132] Tsuji Y, Opthof T, Kamiya K, et al. Pacing-induced heart failure causes a reduction of delayed rectifier potassium currents along with decreases in calcium and transient outward currents in rabbit ventricle. Cardiovasc Res 2000; 48: 300 -9.

[133] Rose J, Armoundas AA, Tian Y, et al. Molecular correlates of altered expression of potassium currents in failing rabbit myocardium. Am J Physiol Heart Circ Physiol 2005; 288: H2077-87.

[134] Roden DM. Taking the idio out of idiosyncratic-predicting torsades de pointes. Pacing Clin Electrophysiol 1998; 21: 1029-34.

[135] Varró A, Baláti $\mathrm{B}$, Iost $\mathrm{N}$, et al. The role of $\mathrm{I}_{\mathrm{Ks}}$ in dog ventricular muscle and Purkinje fibre repolarization. J Physiol 2000; 523: 6781 .

[136] Varró A, Baczkó I. Cardiac ventricular repolarization reserve: a principle for understanding drug-related proarrhythmic risk. $\mathrm{Br} \mathrm{J}$ Pharmacol 2011; 164: 14-36.

[137] Guelon D, Bedock B, Chartier C, et al. QT prolongation and recurrent "torsades de pointes" during erythromycin lactobionate infusion. Am J Cardiol 1986; 58: 666.

[138] Kikuchi K, Nagatomo T, Abe H, et al. Blockade of HERG cardiac $\mathrm{K}^{+}$current by the antifungal drug miconazole. Br J Pharmacol 2005; 144: 840-8.

[139] Berul CI, Morad M. Regulation of potassium channels by nonsedating antihistamines. Circulation 1995; 91: 2220-5.

[140] Titier K, Girodet PO, Verdoux H, et al. Atypical antipsychotics: from potassium channels to torsade de pointes and sudden death. Drug Saf 2005; 28: 35-51
[141] Kristóf A, Husti Z, Koncz I, et al. Diclofenac prolongs repolarization in ventricular muscle with impaired repolarization reserve. PLoS One 2012; 7: e53255.

[142] Zitron E, Scholz E, Owen RW, et al. QTc prolongation by grapefruit juice and its potential pharmacological basis: HERG channel blockade by flavonoids. Circulation 2005; 111: 835-8.

[143] Kannankeril PJ, Roden DM. Drug-induced long QT and torsade de pointes: recent advances. Curr Opin Cardiol 2007; 22: 39-43.

[144] Wijffels MC, Kirchhof CJ, Dorland R, et al. Atrial fibrillation begets atrial fibrillation. A study in awake chronically instrumented goats. Circulation 1995; 92: 1954-68.

[145] Dobrev D, Ravens U. Remodeling of cardiomyocyte ion channels in human atrial fibrillation. Basic Res Cardiol 2003; 98: 137-48

[146] Sun H, Chartier D, Leblanc N, et al. Intracellular calcium changes and tachycardia-induced contractile dysfunction in canine atrial myocytes. Cardiovasc Res 2001; 49: 751-61.

[147] Qi XY, Yeh YH, Xiao L, et al. Cellular signalling underlying atrial tachycardia remodelling of L-type calcium current. Circ Res 2008; 103: $845-54$

[148] van Wagoner DR, Pond AL, Lamorgese M, et al. Atrial L-type $\mathrm{Ca}^{2+}$ currents and human atrial fibrillation. Circ Res 1999; 85: 42836.

[149] Workman AJ, Kane KA, Rankin AC. The contribution of ionic currents to changes in refractoriness of human atrial myocytes associated with chronic atrial fibrillation. Cardiovasc Res 2001; 52: 226-35

[150] Yu WC, Chen SA, Lee SH, et al. Tachycardia-induced change of atrial refractory period in humans: rate dependency and effects of antiarrhythmic drugs. Circulation 1998; 97: 2331-37.

[151] Bosch RF, Zeng X, Grammer JB, et al. Ionic mechanisms of electrical remodelling in human atrial fibrillation. Cardiovasc Res 1999; 44: 121-31.

[152] Wettwer E, Christ T, Endig S, et al. The new antiarrhythmic drug vernakalant: ex vivo study of human atrial tissue from sinus rhythm and chronic atrial fibrillation. Cardiovasc Res 2013; 98: 145-54

[153] Gaspo R, Bosch RF, Bou-Abboud E, et al. Tachycardia-induced changes in $\mathrm{Na}^{+}$current in a chronic dog model of atrial fibrillation. Circ Res 1997; 81:1045-52.

[154] Allessie M, Ausma J, Schotten U. Electrical, contractile and structural remodelling during atrial fibrillation. Cardiovasc Res 2002; 54: $230-46$

[155] Song Y, Shryock JC, Belardinelli L. An increase of late sodium current induces delayed afterdepolarizations and sustained triggered activity in atrial myocytes. Am J Physiol Heart Circ Physiol 2008; 294: H2031-9.

[156] Schotten U, Greiser M, Benke D, et al. Atrial fibrillation-induced atrial contractile dysfunction: a tachycardiomyopathy of a different sort. Cardiovasc Res 2002; 53: 192-201.

[157] Uemura N, Ohkusa T, Hamano K, et al. Down-regulation of sarcolipin mRNA expression in chronic atrial fibrillation. Eur J Clin Invest 2004; 34: 723-30.

[158] Brundel BJ, van Gelder IC, Henning RH, et al. Alterations in potassium channel gene expression in atria of patients with persistent and paroxysmal atrial fibrillation: differential regulation of protein and mRNA levels for $\mathrm{K}^{+}$channels. J Am Coll Cardiol 2001; 37: 926-32.

[159] Dobrev D, Friedrich A, Voigt N, et al. The G protein-gated potassium current $\mathrm{I}_{\mathrm{K}, \mathrm{ACh}}$ is constitutively active in patients with chronic atrial fibrillation. Circulation 2005; 112: 3697-706.

[160] Gaborit N, Steenman M, Lamirault G, et al. Human atrial ion channel and transporter subunit gene-expression remodelling associated with valvular heart disease and atrial fibrillation. Circulation 2005; 112: 471-81.

[161] Pandit SV, Berenfeld O, Anumonwo JM, et al. Ionic determinants of functional reentry in a 2-D model of human atrial cells during simulated chronic atrial fibrillation. Biophys J 2005; 88: 3806-21.

[162] Yue L, Feng J, Gaspo R, et al. Ionic remodelling underlying action potential changes in a canine model of atrial fibrillation. Circ Res 1997; 81: 512-25.

[163] Caballero R, de la Fuente MG, Gómez R, et al. In humans, chronic atrial fibrillation decreases the transient outward current and ultrarapid component of the delayed rectifier current differentially on each atria and increases the slow component of the delayed rectifier current in both. J Am Coll Cardiol 2010; 55: 2346-54. 
[164] Fedida D, Wible B, Wang Z, et al. Identity of a novel delayed rectifier current from human heart with a cloned $\mathrm{K}^{+}$channel current. Circ Res 1993; 73: 210-6.

[165] Schotten U, Verheule S, Kirchhof P, et al. Pathophysiological mechanisms of atrial fibrillation: a translational appraisal. Physiol Rev. 2011; 91: 265-325.

[166] Ford JW, Milnes JT. New drugs targeting the cardiac ultra-rapid delayed-rectifier current $\left(I_{\text {Kur }}\right)$ : rationale, pharmacology and evidence for potential therapeutic value. J Cardiovasc Pharmacol 2008; 52: 105-20.

[167] Ravens U, Wettwer E. Ultra-rapid delayed rectifier channels: molecular basis and therapeutic implications. Cardiovasc Res 2011; 89: 776-85.

[168] Noma A. ATP-regulated $\mathrm{K}^{+}$channels in cardiac muscle. Nature 1983; 305: 147-8.

[169] Deutsch N, Klitzner TS, Lamp ST, et al. Activation of cardiac ATP-sensitive $\mathrm{K}^{+}$current during hypoxia: correlation with tissue ATP levels. Am J Physiol 1991; 261: H671-76.

[170] Baczkó I, Husti Z, Lang V, et al. Sarcolemmal $\mathrm{K}_{\text {ATP }}$ channel modulators and cardiac arrhythmias. Curr Med Chem 2011; 18: 3640-61.

[171] Brundel BJ, van Gelder IC, Henning RH, et al. Ion channel remodelling is related to intraoperative atrial effective refractory periods in patients with paroxysmal and persistent atrial fibrillation. Circulation 2001; 103: 684-90.

[172] Balana B, Dobrev D, Wettwer E, et al. Decreased ATP-sensitive $\mathrm{K}^{+}$current density during chronic human atrial fibrillation. J Mol Cell Cardiol. 2003; 35: 1399-405.

[173] Olson TM, Alekseev AE, Moreau C, et al. $\mathrm{K}_{\mathrm{ATP}}$ channel mutation confers risk for vein of Marshall adrenergic atrial fibrillation. Nat Clin Pract Cardiovasc Med 2007; 4: 110-6.

[174] Dupont E, Matsushita T, Kaba RA, et al. Altered connexin expression in human congestive heart failure. J Mol Cell Cardiol 2001; 33: 359-71.

[175] Kostin S, Rieger M, Dammer S, et al. Gap junction remodeling and altered connexin 43 expression in the failing human heart. Mol Cell Biochem 2003; 242: 135-44.

[176] Poelzing S, Rosenbaum DS. Altered connexin43 expression produces arrhythmia substrate in heart failure. Am J Physiol Heart Circ Physiol 2004; 287: H1762-70.

[177] Glukhov AV, Fedorov VV, Kalish PW, et al. Conduction remodeling in human end-stage nonischemic left ventricular cardiomyopathy. Circulation 2012; 125: 1835-47.

[178] Peters NS. Myocardial gap junction organization in ischemia and infarction. Microsc Res Tech 1995; 31: 375-86.

[179] Polontchouk L, Haefliger JA, Ebelt B, et al. Effects of chronic atrial fibrillation on gap junction distribution in human and rat atria. J Am Coll Cardiol 2001; 38: 883-91.

[180] van der Velden HM, Jongsma HJ. Cardiac gap junctions and connexins: their role in atrial fibrillation and potential as therapeutic targets. Cardiovasc Res 2002; 54: 270-9.

[181] Dhein S, Rothe S, Busch A, et al. Effects of metoprolol therapy on cardiac gap junction remodelling and conduction in human chronic atrial fibrillation. Br J Pharmacol 2011; 164: 607-16.

[182] Magyar J, Bányász T, Szentandrássy N et al. Manipulation of gap junction channels as a promising antiarrhythmic strategy. Curr Pharm Des 2014; in press

[183] Biel M, Schneider A, Wahl C. Cardiac HCN channels: structure, function, and modulation.Trends Cardiovasc Med 2002; 12: 20612.

[184] Cerbai E, Sartiani L, DePaoli P, et al. The properties of the pacemaker current $\mathrm{I}_{\mathrm{F}}$ in human ventricular myocytes are modulated by cardiac disease. J Mol Cell Cardiol 2001; 33: 441-8.

[185] Stillitano F, Lonardo G, Zicha S, et al. Molecular basis of funny current $\left(\mathrm{I}_{\mathrm{f}}\right)$ in normal and failing human heart. J Mol Cell Cardiol 2008; 45: 289-99.

[186] Zicha S, Fernandez-Velasco M, Lonardo G, et al. Sinus node dysfunction and hyperpolarization-activated $(\mathrm{HCN})$ channel subunit remodeling in a canine heart failure model. Cardiovasc Res 2005; 66: $472-81$.

[187] Chen YJ, Chen SA, Chen YC, et al. Effects of rapid atrial pacing on the arrhythmogenic activity of single cardiomyocytes from pulmonary veins: implication in initiation of atrial fibrillation. Circulation 2001; 104: 2849-54.

[188] Marx SO, Reiken S, Hisamatsu Y, et al. PKA phosphorylation dissociates FKBP12.6 from the calcium release channel (ryanodine receptor): defective regulation in failing hearts. Cell 2000; 101: 365-76.

[189] Schwinger RH, Bohm M, Schmidt U, et al. Unchanged protein levels of SERCA II and phospholamban but reduced $\mathrm{Ca}^{2+}$ uptake and $\mathrm{Ca}^{2+}$-ATPase activity of cardiac sarcoplasmic reticulum from dilated cardiomyopathy patients compared with patients with nonfailing hearts. Circulation 1995; 92: 3220-28.

[190] Shannon TR, Pogwizd SM, Bers DM. Elevated sarcoplasmic reticulum $\mathrm{Ca} 2+$ leak in intact ventricular myocytes from rabbits in heart failure. Circ Res 2003; 93: 592-4.

[191] Bers DM, Pogwizd SM, Schlotthauer K. Upregulated Na/Ca exchange is involved in both contractile dysfunction and arrhythmogenesis in heart failure. Basic Res Cardiol 2002; 97 Suppl 1: I36-42.

[192] Studer R, Reinecke H, Bilger J, et al. Gene expression of the cardiac $\mathrm{Na}^{+}-\mathrm{Ca}^{2+}$ exchanger in end-stage human heart failure. Circ Res 1994; 75: 443-53.

[193] Van Gelder IC, Brundel BJ, Henning RH, et al. Alterations in gene expression of proteins involved in the calcium handling in patients with atrial fibrillation. J Cardiovasc Electrophysiol 1999; 10: 55260 .

[194] Hove-Madsen L, Llach A, Bayes-Genis A, et al. Atrial fibrillation is associated with increased spontaneous calcium release from the sarcoplasmic reticulum in human atrial myocytes. Circulation 2004; 110: 1358-63.

[195] Vest JA, Wehrens XH, Reiken SR, et al. Defective cardiac ryanodine receptor regulation during atrial fibrillation. Circulation 2005; 111:2025-32.

[196] Acsai K, Nagy N, Márton Z, et al. Antiarrhythmic potential of drugs targeting the cardiac ryanodine receptor $\mathrm{Ca}^{2+}$ release channel: case study of dantrolene. Curr Pharm Des 2014; in press

[197] Zaza A, Rocchetti M. Calcium store stability as an antiarrhythmic endpoint. Curr Pharm Des 2014; in press

[198] Janse MJ, Wit AL. Electrophysiological mechanisms of ventricular arrhythmias resulting from myocardial ischemia and infarction. Physiol Rev 1989; 69: 1049-169.

[199] Furukawa T, Kimura S, Furukawa N, et al. Role of cardiac ATPregulated potassium channels in differential responses of endocardial and epicardial cells to ischemia. Circ Res 1991; 68: 1693-1702.

[200] Antzelevitch C, Fish J. Electrical heterogeneity within the ventricular wall. Basic Res Cardiol 2001; 96: 517-27.

[201] Taggart P, Sutton PM, Opthof T, et al. Transmural repolarisation in the left ventricle in humans during normoxia and ischaemia. Cardiovasc Res 2001; 50: 454-62.

[202] Taggart P, Sutton PM, et al. Inhomogeneous transmural conduction during early ischaemia in patients with coronary artery disease. $\mathrm{J}$ Mol Cell Cardiol 2000; 32: 621-30.

[203] Kléber AG. Resting membrane potential, extracellular potassium activity, and intracellular sodium activity during acute global ischemia in isolated perfused guinea pig hearts. Circ Res 1983; 52: $442-50$.

[204] Johnson TA, Engle CL, Boyd LM, et al. Magnitude and time course of extracellular potassium inhomogeneities during acute ischemia in pigs. Effect of verapamil. Circulation 1991; 83: 622-34

[205] Kiyosue T, Arita M. Late sodium current and its contribution to action potential configuration in guinea pig ventricular myocytes. Circ Res 1989; 64: 389-97.

[206] Liu Y-M, DeFelice LJ, Mazzanti M. Na channels that remain open throughout the cardiac action potential plateau. Biophys J 1992; 63 : 654-62.

[207] Saint DA. The cardiac persistent sodium current: an appealing therapeutic target? Br J Pharmacol 2008; 153: 1133-42.

[208] Undrovinas AI, Fleidervish IA, Makielski JC. Inward sodium current at resting potentials in single cardiac myocytes induced by the ischemic metabolite lysophosphatidylcholine. Circ Res 1992; 71: $1231-41$.

[209] Bennett PB, Yazawa K, Makita N, et al. Molecular mechanism for an inherited cardiac arrhythmia. Nature 1995; 376: 683-5.

[210] Undrovinas AI, Maltsev VA, Kyle JW, et al. Gating of the late $\mathrm{Na}^{+}$ channel in normal and failing human myocardium. J Mol Cell Cardiol 2002; 34: 1477-89.

[211] Sossalla S, Kallmeyer B, Wagner S, et al. Altered $\mathrm{Na}^{+}$currents in atrial fibrillation effects of ranolazine on arrhythmias and contractility in human atrial myocardium. J Am Coll Cardiol 2010; 55: $2330-42$. 
[212] Horvath B, Banyasz T, Jian Z, et al. Dynamics of the late $\mathrm{Na}^{+}$ current during cardiac action potential and its contribution to afterdepolarizations. J Mol Cell Cardiol 2013; 64: 59-68.

[213] Coulombe A, Coraboeuf E, Malecot C, et al. Role of the "Na window" current and other ionic currents in triggering early afterdepolarizations and resulting re-excitation in Purkinje fibers. In: Zipes DP, Jalife J, Eds. Cardiac Electrophysiology and Arrhythmias, New York: Grune and Stratton 1985: pp.43-9.

[214] Undrovinas A, Maltsev VA. Late sodium current is a new therapeutic target to improve contractility and rhythm in failing heart. Cardiovasc Hematol Agents Med Chem 2008; 6: 348-59.

[215] Burashnikov A, Antzelevitch C. Role of late sodium channel current block in the management of atrial fibrillation. Cardiovasc Drugs Ther 2013; 27: 79-89.

[216] Maltsev VA, Sabbah HN, Undrovinas AI. Late sodium current is a novel target for amiodarone: studies in failing human myocardium. J Mol Cell Cardiol 2001; 33: 923-32.

[217] Brisdelli F, D’Andrea G, Bozzi A. Resveratrol: a natural polyphenol with multiple chemopreventive properties. Curr Drug Metab 2009; 10: 530-46.

[218] Wallace CH, Baczkó I, Jones L, et al. Inhibition of cardiac voltagegated sodium channels by grape polyphenols. Br J Pharmacol 2006; 149: 657-65.

[219] Rousseau MF, Pouleur H, Cocco G, et al. Comparative efficacy of ranolazine versus atenolol for chronic angina pectoris. Am J Cardiol 2005; 95: 311-6.

[220] Antzelevitch C, Burashnikov A, Sicouri S, et al. Electrophysiologic basis for the antiarrhythmic actions of ranolazine. Heart Rhythm 2011; 8: 1281-90.

[221] Szél T, Koncz I, Jost N, et al. Class I/B antiarrhythmic property of ranolazine, a novel antianginal agent, in dog and human cardiac preparations. Eur J Pharmacol. 2011; 662: 31-9.

[222] Song Y, Shryock JC, Wu L, et al. Antagonism by ranolazine of the pro-arrhythmic effects of increasing late $\mathrm{I}_{\mathrm{Na}}$ in guinea pig ventricular myocytes. J Cardiovasc Pharmacol 2004; 44: 192-9.

[223] Undrovinas AI, Belardinelli L, Undrovinas NA, et al. Ranolazine improves abnormal repolarization and contraction in left ventricular myocytes of dogs with heart failure by inhibiting late sodium current. J Cardiovasc Electrophysiol 2006; 17 Suppl. 1: S169-77.

[224] Antoons G, Oros A, Beekman JD, et al. Late $\mathrm{Na}^{+}$current inhibition by ranolazine reduces torsades de pointes in the chronic atrioventricular block dog model. J Am Coll Cardiol 2010; 55: 801-9.

[225] Volders PG, Sipido KR, Vos MA, et al. Downregulation of delayed rectifier $\mathrm{K}^{+}$currents in dogs with chronic complete atrioventricular block and acquired torsades de pointes. Circulation 1999; 100: 2455-61

[226] Schram G, Zhang L, Derakhchan K, et al. Ranolazine: ion-channelblocking actions and in vivo electrophysiological effects. $\mathrm{Br} \mathrm{J}$ Pharmacol 2004; 142: 1300-8.

[227] Rajamani S, Shryock JC, Belardinelli L. Rapid kinetic interactions of ranolazine with HERG $\mathrm{K}^{+}$current. J Cardiovasc Pharmacol 2008; 51: 581-9.

[228] Chaitman BR. Ranolazine for the treatment of chronic angina and potential use in other cardiovascular conditions. Circulation. 2006; 113: 2462-72.

[229] Sossalla S, Wallisch N, Toischer K, et al. Effects of Ranolazine on Torsades de Pointes Tachycardias in a Healthy Isolated Rabbit Heart Model. Cardiovasc Ther. 2014 Apr 30. Published online

[230] Smith-Maxwell CJ, Xie C, Chan K, et al. Discovery of GS-458967: a novel and highly selective inhibitor of cardiac sodium channel late current. Heart Rhythm 2012; 9 Suppl. 5: S394.

[231] Belardinelli L, Liu G, Smith-Maxwell C, et al. A novel, potent, and selective inhibitor of cardiac late sodium current suppresses experimental arrhythmias. J Pharmacol Exp Ther 2013; 344: 23-32.

[232] Sicouri S, Belardinelli L, Antzelevitch C. Antiarrhythmic effects of the highly selective late sodium channel current blocker GS458967. Heart Rhythm 2013; 10: 1036-43.

[233] Baczkó I, Liknes D, Yang W, et al. Characterization of a novel multi-functional resveratrol derivative for the treatment of atrial fibrillation. Br J Pharmacol 2014; 171: 92-106.

[234] Pignier C, Rougier JS, Vie B, et al. Selective inhibition of persistent sodium current by F 15845 prevents ischaemia-induced arrhythmias. Br J Pharmacol 2010; 161: 79-91.

[235] Bányász T, Magyar J, Szentandrássy N, et al. An emerging antiarrhythmic target: the late sodium current. Curr Pharm Des 2014; in press
[236] Tomaselli GF, Zipes DP. What causes sudden death in heart failure? Circ Res 2004; 95: 754-63.

[237] Yan GX, Rials SJ, Wu Y, et al. Ventricular hypertrophy amplifies transmural repolarization dispersion and induces early afterdepolarization. Am J Physiol 2001; 281: H1968- 75.

[238] Hansen RS, Diness TG, Christ T, et al. Biophysical characterization of the new human ether-a-go-go-related gene channel opener NS3623 [N-(4-bromo-2-(1H-tetrazol-5-yl)-phenyl)-N'-(3'trifluoromethylphenyl)urea]. Mol Pharmacol 2006; 70: 1319-29.

[239] Kang J, Chen XL, Wang H, et al. Discovery of a small molecule activator of the human ether-a-go-go-related gene (HERG) cardiac $\mathrm{K}^{+}$channel. Mol Pharmacol 2005; 67: 827-36.

[240] Zhou J, Augelli-Szafran CE, Bradley JA, et al. Novel potent human ether-a-go-go-related gene (hERG) potassium channel enhancers and their in vitro antiarrhythmic activity. Mol Pharmacol 2005; 68: 876-84.

[241] Casis O, Olesen SP, Sanguinetti MC. Mechanism of action of a novel human ether-a-go-go-related gene channel activator. Mol Pharmacol 2006; 69: 658-65.

[242] Hansen RS, Diness TG, Christ T, et al. Activation of human ethera-go-go-related gene potassium channels by the diphenylurea 1, 3bis-(2-hydroxy-5-trifluoromethyl-phenyl)-urea (NS1643). Mol Pharmacol 2006; 69: 266-77.

[243] Jost N, Papp JG, Varró A. Slow delayed rectifier potassium current $\left(\mathrm{I}_{\mathrm{Ks}}\right)$ and the repolarization reserve. Ann Noninvasive Electrocardiol 2007; 12: 64-78.

[244] Perry M, Sachse FB, Sanguinetti MC. Structural basis of action for a human ether-a-go-go-related gene 1 potassium channel activator. Proc Natl Acad Sci USA 2007; 104: 13827-32.

[245] Gerlach AC, Stoehr SJ, Castle NA. Pharmacological removal of human ether-à-go-go-related gene potassium channel inactivation by 3-nitro-N-(4-phenoxyphenyl) benzamide (ICA-105574). Mol Pharmacol 2010; 77: 58-68.

[246] Meng J, Shi C, Li L, et al. Compound ICA-105574 prevents arrhythmias induced by cardiac delayed repolarization. Eur J Pharmacol 2013; 718: 87-97.

[247] Diness TG, Yeh YH, Qi XY, et al. Antiarrhythmic properties of a rapid delayed-rectifier current activator in rabbit models of acquired long QT syndrome. Cardiovasc Res 2008; 79: 61-9.

[248] Tsuji Y, Zicha S, Qi X-Y, et al. Potassium channel subunit remodeling in rabbits exposed to long-term bradycardia or tachycardia: discrete arrhythmogenic consequences related to differential delayed-rectifier changes. Circulation 2006; 113: 345-55.

[249] Carlsson L, Abrahamsson C, Andersson B, et al. Proarrhythmic effects of the class III agent almokalant: importance of infusion rate, QT dispersion, and early afterdepolarisations. Cardiovasc Res 1993; $27:$ 2186-93.

[250] Bentzen BH, Bahrke S, Wu K, et al. Pharmacological activation of Kv11.1 in transgenic long QT-1 rabbits. Cardiovasc Pharmacol 2011; 57: 223-30.

[251] Hansen RS, Olesen SP, Rønn LC, et al. In vivo effects of the $\mathrm{I}_{\mathrm{Kr}}$ agonist NS3623 on cardiac electrophysiology of the guinea pig. J Cardiovasc Pharmacol 2008; 52: 35-41.

[252] Larsen AP, Olesen SP, Grunnet M, et al. Pharmacological activation of $\mathrm{I}_{\mathrm{Kr}}$ impairs conduction in guinea pig hearts. J Cardiovasc Electrophysiol 2010; 21: 923-9.

[253] Jost, N., Virág, L., Bitay, M., et al. Restricting excessive cardiac action potential and QT prolongation: a vital role for $\mathrm{I}_{\mathrm{Ks}}$ in human ventricular muscle. Circulation 2005; 112: 1392-9.

[254] Salata JJ, Jurkiewicz NK, Wang J, et al. A novel benzodiazepine that activates cardiac slow delayed rectifier $\mathrm{K}^{+}$currents. Mol Pharmacol 1998; 54: 220-30.

[255] Xu X, Salata JJ, Wang J, et al. Increasing $\mathrm{I}_{\mathrm{Ks}}$ corrects abnormal repolarization in rabbit models of acquired LQT2 and ventricular hypertrophy. Am J Physiol Heart Circ Physiol 2002; 283: H664-70.

[256] Magyar J, Horváth B, Bányász T, et al. L-364, 373 fails to activate the slow delayed rectifier $\mathrm{K}^{+}$current in canine ventricular cardiomyocytes. Naunyn Schmiedebergs Arch Pharmacol 2006; 373: 8590.

[257] Nissen JD, Diness JG, Diness TG, et al. Pharmacologically induced long QT Type 2 can be rescued by activation of $\mathrm{I}_{\mathrm{Ks}}$ with benzodiazepine R-L3 in isolated guinea pig cardiomyocytes. J Cardiovasc Pharmacol 2009; 54: 169-77.

[258] Corici C, Kohajda Z, Kristóf A, et al. L-364, 373 (R-L3) enantiomers have opposite modulating effects on $\mathrm{I}_{\mathrm{Ks}}$ in mammalian ventricular myocytes. Can J Physiol Pharmacol 2013; 91: 586-92. 
[259] Jespersen T, Grunnet M, Olesen SP. The KCNQ1 potassium channel: from gene to physiological function. Physiology (Bethesda). 2005; 20: 408-16.

[260] Sah R, Ramirez RJ, Backx PH. Modulation of $\mathrm{Ca}^{2+}$ release in cardiac myocytes by changes in repolarization rate: role of phase-1 action potential repolarization in excitation-contraction coupling. Circ Res 2002; 90: 165-73.

[261] Calloe K, Nof E, Jespersen T, et al. Comparison of the effects of a transient outward potassium channel activator on currents recorded from atrial and ventricular cardiomyocytes. J Cardiovasc Electrophysiol 2011; 22: 1057-66.

[262] Burashnikov A, Di Diego JM, Zygmunt AC, et al. Atrium-selective sodium channel block as a strategy for suppression of atrial fibrillation: Differences in sodium channel inactivation between atria and ventricles and the role of ranolazine. Circulation 2007; 116: 144957.

[263] Cordeiro JM, Calloe K, Moise NS, et al. Physiological consequences of transient outward $\mathrm{K}^{+}$current activation during heart failure in the canine left ventricle. J Mol Cell Cardiol 2012; 52: 1291-8.

[264] Spinelli W, Sorota S, Siegal M, et al. Antiarrhythmic actions of the ATP-regulated $\mathrm{K}^{+}$current activated by pinacidil. Circ Res 1991; 68: $1127-37$

[265] Ueda H, Nakayama Y, Tsumura K, et al. Intravenous nicorandil can reduce the occurrence of ventricular fibrillation and QT dispersion in patients with successful coronary angioplasty in acute myocardial infarction. Can J Cardiol 2004; 20: 625-9.

[266] Yang Z, Shi G, Li C, et al. Electrophysiologic effects of nicorandil on the guinea pig long QT1 syndrome model. J Cardiovasc Electrophysiol 2004; 15: 815-20.

[267] Sato T, Hata Y, Yamamoto M, et al. Early afterdepolarization abolished by potassium channel opener in a patient with idiopathic long QT syndrome. J Cardiovasc Electrophysiol 1995; 6: 279-82.

[268] Shimizu W, Kurita T, Matsuo K, et al. Improvement of repolarization abnormalities by a $\mathrm{K}^{+}$channel opener in the LQT1 form of congenital long-QT syndrome. Circulation 1998; 97: 1581-8.

[269] Shimizu W, Antzelevitch C. Effects of a $\mathrm{K}^{+}$channel opener to reduce transmural dispersion of repolarization and prevent torsade de pointes in LQT1, LQT2, and LQT3 models of the long-QT syndrome. Circulation 2000; 102: 706-12.

[270] Baczkó I, Jones L, McGuigan CF, et al. Plasma membrane $\mathrm{K}_{\text {ATP }}$ channel-mediated cardioprotection involves posthypoxic reductions in calcium overload and contractile dysfunction: mechanistic insights into cardioplegia. FASEB J 2005; 19: 980-2.

[271] Baczkó I, Giles WR, Light PE. Pharmacological activation of plasma-membrane $\mathrm{K}_{\text {ATP }}$ channels reduces reoxygenation-induced $\mathrm{Ca}^{2+}$ overload in cardiac myocytes via modulation of the diastolic membrane potential. Br J Pharmacol 2004; 141: 1059-67.

[272] Baczkó I, Giles WR, Light PE. Resting membrane potential regulates $\mathrm{Na}^{+} / \mathrm{Ca}^{2+}$ exchange-mediated $\mathrm{Ca}^{2+}$ overload during hypoxia/reoxygenation in rat ventricular myocytes. J Physiol 2003; 550: 889-98.

[273] Chi L, Uprichard AC, Lucchesi BR. Profibrillatory actions of pinacidil in a conscious canine model of sudden coronary death. J Cardiovasc Pharmacol 1990; 15: 452-64.

[274] Bauer A, Becker R, Dreyhaupt J, et al. Role of $\mathrm{K}_{\mathrm{ATP}}$ channels in repetitive induction of ventricular fibrillation. Europace 2007; 9: $154-61$.

[275] Fedorov VV, Glukhov AV, Ambrosi CM, et al. Effects of $\mathrm{K}_{\text {ATP }}$ channel openers diazoxide and pinacidil in coronary-perfused atria and ventricles from failing and non-failing human hearts. J Mol Cell Cardiol 2011; 51: 215-25.

[276] Billman GE. The cardiac sarcolemmal ATP-sensitive potassium channel as a novel target for anti-arrhythmic therapy. Pharmacol Ther 2008; 120: 54-70.

[277] Pountney DJ, Sun ZQ, Porter LM et al. Is the molecular composition of $\mathrm{K}_{\text {ATP }}$ channels more complex than originally thought? J Mol Cell Cardiol 2001; 33: 1541-6.

[278] Tricarico D, Mele A, Lundquist AL et al. Hybrid assemblies of ATP-sensitive $\mathrm{K}^{+}$channels determine their muscle-type-dependent biophysical and pharmacological properties. Proc Natl Acad Sci USA 2006; 103: 1118-23.

[279] Muntean DM, Jost N, Baczko I. ATP-sensitive potassium channel modulators and cardiac arrhythmias: an update. Curr Pharm Des 2014 in press
[280] Wang Z, Fermini B, Nattel S. Sustained depolarization induced outward current in human atrial myocytes. Evidence for a novel delayed rectifier $\mathrm{K}^{+}$current similar to Kv1.5 cloned channel currents. Circ Res 1993; 73: 1061-76.

[281] Ford JW, Milnes JT. New drugs targeting the cardiac ultra-rapid delayed-rectifier current $\left(\mathrm{I}_{\mathrm{Kur}}\right)$ : rationale, pharmacology and evidence for potential therapeutic value. J Cardiovasc Pharmacol 2008; $52: 105-20$.

[282] Grammer JB, Bosch RF, Kühlkamp V, et al. Molecular remodeling of Kv4.3 potassium channels in human atrial fibrillation. J Cardiovasc Electrophysiol 2000; 11: 626-33.

[283] Krapivinsky G, Gordon EA, Wickman K, et al. The G-proteingated atrial $\mathrm{K}^{+}$channel $\mathrm{I}_{\mathrm{KACh}}$ is a heteromultimer of two inwardly rectifying $\mathrm{K}^{+}$-channel proteins. Nature $1995 ; 374$ : 135-41.

[284] Liu L, Nattel S. Differing sympathetic and vagal effects on atrial fibrillation in dogs: role of refractoriness heterogeneity. Am J Physiol 1997; 273: H805-16.

[285] Cha TJ, Ehrlich JR, Chartier D, et al. Kir3-based inward rectifier potassium current: potential role in atrial tachycardia remodeling effects on atrial repolarization and arrhythmias. Circulation 2006; 113: $1730-7$.

[286] Hashimoto N, Yamashita T, Tsuruzoe N. Tertiapin, a selective $\mathrm{I}_{\mathrm{KACh}}$ blocker, terminates atrial fibrillation with selective atrial effective refractory period prolongation. Pharmacol Res 2006; 54: 136-41.

[287] Matsuda T, Ito M, Ishimaru S, et al. Blockade by NIP-142, an antiarrhythmic agent, of carbachol-induced atrial action potential shortening and GIRK1/4 channel. J Pharmacol Sci 2006; 101: 303 10.

[288] Hashimoto N, Yamashita T, Fujikura N, et al. NIP-141, a multiple ion channel blocker, terminates aconitine-induced atrial fibrillation and prevents the rapid pacing-induced atrial effective refractory period shortening in dogs. Europace 2007; 9: 246-51.

[289] Hashimoto N, Yamashita T, Tsuruzoe N. Characterization of in vivo and in vitro electrophysiological and antiarrhythmic effects of a novel $\mathrm{I}_{\mathrm{KACh}}$ blocker, NIP-151: a comparison with an $\mathrm{I}_{\mathrm{Kr}}$-blocker dofetilide. J Cardiovasc Pharmacol 2008; 51: 162-9.

[290] Machida T, Hashimoto N, Kuwahara I, et al. Effects of a highly selective acetylcholine-activated $\mathrm{K}^{+}$channel blocker on experimental atrial fibrillation. Circ Arrhythm Electrophysiol 2011; 4: 94102.

[291] Tanaka H, Hashimoto N. A multiple ion channel blocker, NIP-142, for the treatment of atrial fibrillation. Cardiovasc Drug Rev 2007; 25: $342-56$

[292] Hobai IA, Maack C, O'Rourke B. Partial inhibition of sodium/calcium exchange restores cellular calcium handling in canine heart failure. Circ Res 2004; 95: 292-9.

[293] Nagy ZA, Virág L, Tóth A, et al. Selective inhibition of sodiumcalcium exchanger by SEA-0400 decreases early and delayed after depolarization in canine heart. Br J Pharmacol 2004; 143: 827-31.

[294] Birinyi P, Acsai K, Bányász T, et al. Effects of SEA0400 and KBR7943 on $\mathrm{Na}^{+} / \mathrm{Ca}^{2+}$ exchange current and L-type $\mathrm{Ca}^{2+}$ current in canine ventricular cardiomyocytes. Naunyn Schmiedebergs Arch Pharmacol 2005; 372: 63-70.

[295] Jost N, Nagy N, Corici C, et al. ORM-10103, a novel specific inhibitor of the $\mathrm{Na}^{+} / \mathrm{Ca}^{2+}$ exchanger, decreases early and delayed afterdepolarizations in the canine heart. Br J Pharmacol 2013; 170 768-78.

[296] Böhm M, Swedberg K, Komajda M, et al. Heart rate as a risk factor in chronic heart failure (SHIFT): the association between heart rate and outcomes in a randomised placebo-controlled trial. Lancet 2010; 376: 886-94.

[297] Fox K, Garcia MA, Ardissino D, et al. Guidelines on the management of stable angina pectoris: executive summary: The Task Force on the Management of Stable Angina Pectoris of the European Society of Cardiology. Eur Heart J 2006; 27: 1341-81.

[298] Fox K, Komajda M, Ford I, et al. Effect of ivabradine in patients with left-ventricular systolic dysfunction: a pooled analysis of individual patient data from the BEAUTIFUL and SHIFT trials. Eur Heart J. 2013; 34: 2263-70.

[299] Vilaine JP, Thollon C, Villeneuve N, et al. Procoralan, a new selective $\mathrm{I}_{\mathrm{f}}$ current inhibitor. Eur. Heart J 2003; 5 Suppl: 26-35.

[300] Koncz I, Szél T, Bitay M, et al. Electrophysiological effects of ivabradine in dog and human cardiac preparations: potential antiarrhythmic actions. Eur J Pharmacol 2011; 668: 419-26. 
[301] Melchiorre M, Del Lungo M, Guandalini L, et al. Design, synthesis, and preliminary biological evaluation of new isoform-selective f-current blockers. J Med Chem 2010; 53: 6773-7.

[302] Del Lungo M, Melchiorre M, Guandalini L, et al. Novel blockers of hyperpolarization-activated current with isoform selectivity in recombinant cells and native tissue. Br J Pharmacol 2012; 166: 602-16.

[303] Zimetbaum PJ. Dronedarone for atrial fibrillation - an odyssey. N Engl J Med 2009; 360: 1811-3.

[304] Dorian P, Pinter A, Mangat I, Korley V, Cvitkovic SS, Beatch GN. The effect of vernakalant (RSD1235), an investigational antiarrhythmic agent, on atrial electrophysiology in humans. J Cardiovasc Pharmacol 2007; 50: 35-40.

[305] Roy D, Rowe BH, Stiell IG, et al. A randomized, controlled trial of RSD1235, a novel anti-arrhythmic agent, in the treatment of recent onset atrial fibrillation. J Am Coll Cardiol 2004; 44: 2355-61.

[306] Roy D, Pratt CM, Torp-Pedersen C, et al. Vernakalant hydrochloride for rapid conversion of atrial fibrillation: a phase 3, randomized, placebo-controlled trial. Circulation. 2008; 117: 1518-25.

[307] Kowey PR, Dorian P, Mitchell LB, et al. Vernakalant hydrochloride for the rapid conversion of atrial fibrillation after cardiac surgery: a randomized, double-blind, placebo-controlled trial. Circ Arrhythm Electrophysiol 2009; 2: 652-9.

[308] Torp-Pedersen C, Raev DH, Dickinson G, Butterfield NN, Mangal B, Beatch GN. A randomized, placebo-controlled study of vernakalant (oral) for the prevention of atrial fibrillation recurrence after cardioversion. Circ Arrhythm Electrophysiol 2011; 4: 637-43.
[309] Varkevisser R, van der Heyden MA, Tieland RG, Beekman JD, Vos MA. Vernakalant is devoid of proarrhythmic effects in the complete AV block dog model. Eur J Pharmacol 2013; 720: 49-54.

[310] Orth PM, Hesketh JC, Mak CK, et al. RSD1235 blocks late $\mathrm{I}_{\mathrm{Na}}$ and suppresses early afterdepolarizations and torsades de pointes induced by classIII agents. Cardiovasc Res 2006; 70: 486-496.

[311] Tsuji Y, Dobrev D. Safety and efficacy of vernakalant for acute cardioversion of atrial fibrillation: an update. Vasc Health Risk Manag 2013; 9: 165-75.

[312] Dobrev D, Nattel S. New antiarrhythmic drugs for treatment of atrial fibrillation. Lancet 2010; 375: 1212-1223.

[313] Dobrev D, Carlsson L, Nattel S. Novel molecular targets for atrial fibrillation therapy. Nat Rev Drug Discov 2012; 11: 275-291.

[314] Chan AY, Dolinsky VW, Soltys CL, et al. Resveratrol inhibits cardiac hypertrophy via AMP-activated protein kinase and Akt. J Biol Chem 2008, 283: 24194-201.

[315] Lin CC, Lin JL, Lin CS, et al. Activation of the calcineurin-nuclear factor of activated T-cell signal transduction pathway in atrial fibrillation. Chest 2004; 126: 1926-32.

[316] Wilkins BJ, Dai YS, Bueno OF, et al. Calcineurin/NFAT coupling participates in pathological, but not physiological, cardiac hypertrophy. Circ Res 2004; 94: 110-118.

[317] Dolinsky VW, Chan AY, Robillard Frayne I, Light PE, Des Rosiers C, Dyck JR. Resveratrol prevents the prohypertrophic effects of oxidative stress on LKB1. Circulation 2009; 119: 1643-1652. 